Document downloaded from:

http://hdl.handle.net/10251/104864

This paper must be cited as:

Alós-Moya, J.; Paya-Zaforteza, I.; Hospitaler Pérez, A.; Rinaudo, P. (2017). Valencia bridge fire tests: Experimental study of a composite bridge under fire. Journal of Constructional Steel Research. 138:538-554. doi:10.1016/j.jcsr.2017.08.008

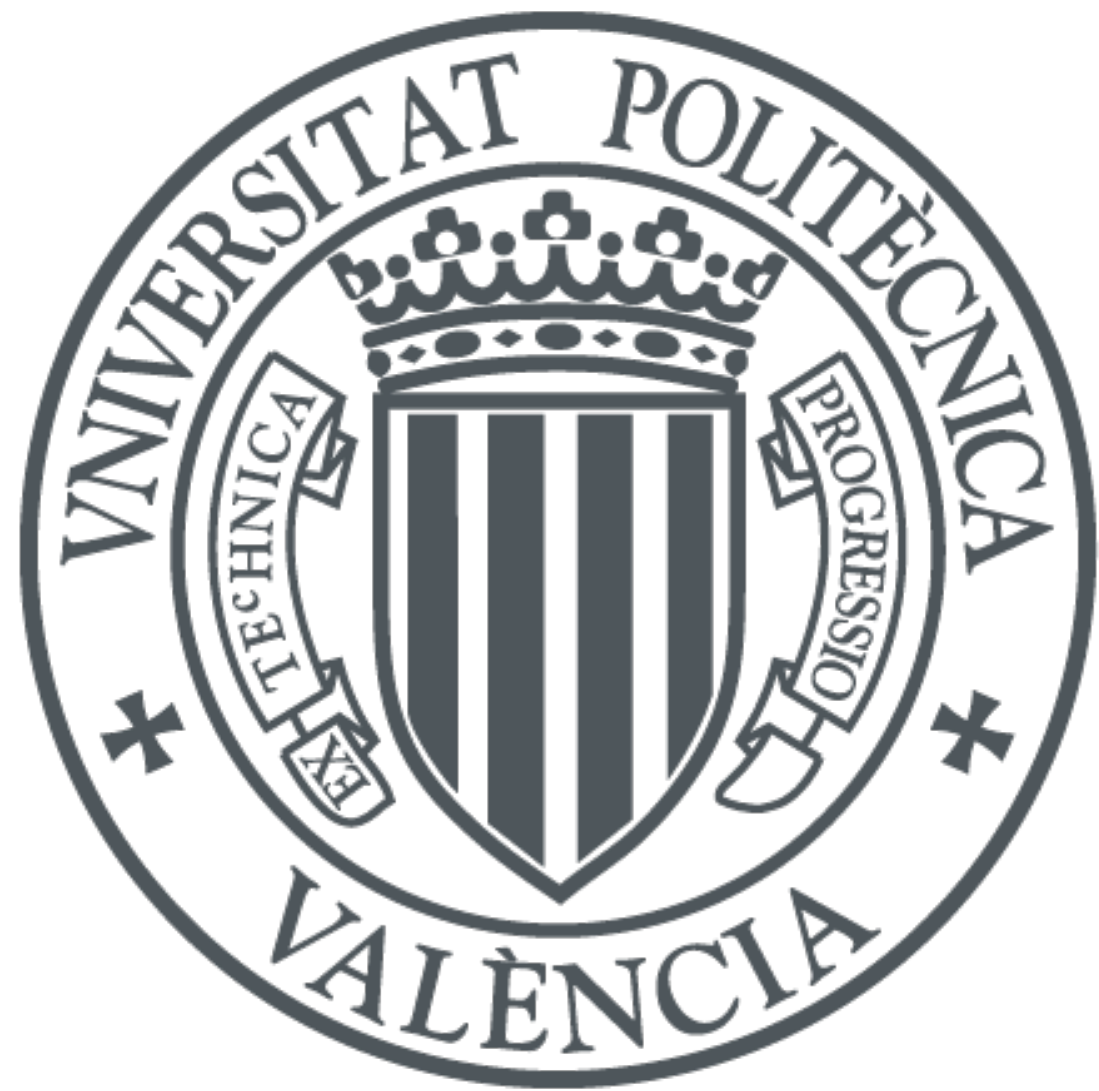

The final publication is available at

http://doi.org/10.1016/j.jcsr.2017.08.008

Copyright Elsevier

Additional Information 


\section{Please cite this paper as:}

Alos-Moya J., Paya-Zaforteza I., Hospitaler A., Rinaudo P. Valencia bridge fire tests: Experimental study of a composite bridge under fire (2017) Journal of Constructional Steel Research, 138, pp. 538-554. DOI: 10.1016/j.jcsr.2017.08.008

\section{Highlights.}

Results from eight fire tests conducted under a composite bridge are presented

Gas and steel temperatures vary significantly along the longitudinal axis of the bridge

Bottom flange and web temperatures are similar and higher than top web temperatures

Fire magnitude and fire position are the key factors in bridge response

This study enables the calibration of numerical models to study bridge fires 


\title{
Valencia bridge fire tests: Experimental study of a composite bridge under fire
}

\author{
Jose Alos-Moya $^{1}$, Ignacio Paya-Zaforteza ${ }^{1 *}$, Antonio Hospitaler ${ }^{1}$, Paula Rinaudo ${ }^{1}$ \\ ${ }^{1}$ ICITECH, Departamento de Ingeniería de la Construcción, Universitat Politècnica de València. Camino de \\ Vera s/n, 46022 Valencia, Spain \\ Authors' e-mail addresses:

$\begin{array}{ll}\text { José Alos-Moya: } & \text { joalmo11@upv.es } \\ \text { Ignacio Paya-Zaforteza: } & \text { igpaza@cst.upv.es } \\ \text { Antonio Hospitaler: } & \text { ahospitaler@cst.upv.es } \\ \text { Paula Rinaudo } & \text { pauri@alumni.upv.es }\end{array}$

\begin{abstract}
The consequences of bridge fires and the lack of guidelines on the evaluation of the fire resistance of bridges have triggered a lot of recent research. Most of these studies are based on numerical models and thus need validation by experimental studies.
\end{abstract}

This paper aims to bridge this gap by describing a battery of open air fire tests carried out under an experimental bridge at the Universitat Politècnica de València in Valencia, Spain. The bridge, with a $6 \mathrm{~m}$ span and a composite deck with two steel l-girders supporting an RC slab, was submitted to four different fire scenarios similar to those of real bridge fires, although smaller in magnitude. Results show that: (a) maximum gas temperatures are reached in the region between the I-girders, (b) as gas and steel temperatures vary significantly along the longitudinal axis of the bridge, it is unrealistic to assume a longitudinally uniform gas or girder temperature (c) temperatures in the bottom flange and the web of the I-girders are very similar and significantly higher than top web temperatures, and (d) the magnitude of the fire load and its position are key factors in the bridge response. This study is of major importance as it enables the validation of the numerical models used in bridge fire engineering and is a crucial step towards the development of a performancebased approach for the design of bridges against fires. The information given will also be useful to those interested in carrying out open air experimental bridge fire tests.

Keywords: Valencia bridge fire tests; steel-concrete composite bridge; mass loss rate; bridge fire; bridge resilience.

* Corresponding author. Tel: +34 963875623; fax: +34 963877568 
Alos-Moya J., Paya-Zaforteza I., Hospitaler A., Rinaudo P.

Valencia bridge fire tests: Experimental study of a composite bridge under fire (2017) Journal of Constructional Steel Research, 138, pp. 538-554. DOI: 10.1016/j.jcsr.2017.08.008

\section{Introduction}

As bridges are a critical component of the road transport infrastructure, a lot of effort has been put into designing them to withstand accidental extreme load events, such as earthquakes, winds, scour, and ship collisions (e.g. Ghosn et al. [1]). Recent studies (PerisSayol et al. [2], Wright et al. [3] and Garlock et al. [4]) have shown that fire is also a major hazard for bridges and highlight the lack of guidelines in current codes on how to estimate a bridge fire resistance.

The serious consequences that can arise from a bridge fire can be illustrated by two fire events: an overturned tanker truck in the MacArthur Maze in Oakland, USA on April 29th 2007 caused the collapse of two spans of the Maze. This collapse resulted in repairs and rebuilding operations costing more than US $\$ 9$ million [5] and indirect costs due to traffic detours of US $\$ 6$ million per day [6]. The second example is the fire caused by a tanker truck that overturned when crossing the Mathilde Bridge in Rouen (France) on October $29^{\text {th }} 2012$, caught fire and spilled fuel that set fire to some trucks parked under the bridge. The bridge suffered severe damage and had to be closed until August $26^{\text {th }} 2014$, almost two years afterwards. The total cost associated with this event has been estimated at $€ 18$ million [7].

Traditionally, fire engineering has paid a lot of attention to mitigating the effects of fires in buildings and tunnels (see e.g. Fischer and Varma [8], Gernay et al. [9], Rodrigues and Laím [10], Rinaudo et al. [11]). However, as can be seen in Table 1, bridge fires have specific features that distinguish them from building and tunnel fires, which together with the gap in the current codes, have generated a lot of research on this topic in recent years. Garlock et al. [4] carried out a detailed review of incidents, case studies and assessment and repair strategies related to bridge fires. This study was complemented by Peris-Sayol et al. [2], who used statistical tools to collect and analyze data from 154 bridge fires and proposed a classification of bridge fire damage levels. The study showed that the bridge vertical clearance and deck material, the type of vehicle involved in the fire, the fuel carried by the vehicle and its position, were the main factors involved in the extent of bridge damage. Other researchers (Naser and Kodur [20], Gil et al. [21]) have proposed specific risk analysis methodologies, while others have used different approaches to study bridges fire response, including the use of fire curves (see e.g. the study on a steel girder bridge by Payá-Zaforteza and Garlock [12]), simplified methodologies based on the calculation of radiation heat fluxes applied to fires below steel and composite girder bridges (Quiel et al. [22]) or Computational Fluid Dynamics models of: (a) fire events below steel and composite bridges (Alós-Moya et al. [23], Peris-Sayol et al. [24, 25], Wright et al. [3]), (b) a fire event in a long-span truss 
bridge (Gong and Agraval [26]) and (c) fires below and on the deck of cable supported bridges (Gong and Agraval [27]).

Experimental work on bridge fires is quite scarce due to the dimensions of bridge elements and the fire loads required, being noteworthy the work by Aziz et al. [28], who experimentally and numerically analyzed the fire performance of steel girders similar to those used in bridges. The girders spanned $3.658 \mathrm{~m}$ and were uniformly heated along their length in a furnace with the standard fire curve. The work by Aziz et al [28] is an important contribution but it also has limitations that justify additional experimental research on bridge fires, including: (1) the standard fire curve is a cellulosic fire curve developed for building fires and is not representative of bridge fires, (2) bridge fires do not uniformly heat girders along their length and cross section, (3) bridge fires happen in the open air in conditions different to those in a furnace and (4) the bridge expansion joints should be considered in the experiments, since they can play a major role in the structural response, as has been shown by [12, 23-25].

Within this general context, this paper details the procedures and results of a battery of fire tests conducted on an experimental bridge with a composite deck at the campus of the Universitat Politècnica de València in Valencia, Spain. The tests described here are of major importance, because, as far as the authors know, this is the first time that an entire bridge has been submitted to a number of different realistic fire scenarios, although of smaller fire load magnitude, and a complete set of thermal and structural results is provided. These results could subsequently be used to calibrate the numerical models used in bridge fire engineering. The experimental validation of these models is crucial to adequately predict the damage fires can cause on bridges and therefore to increase bridge resilience through the development of a performance-based approach to protect bridges from fires. The paper also provides interesting qualitative and quantitative information on bridge fire response, as well as detailed information that will be useful to those interested in carrying out open air experimental tests involving bridge fires. 
Table 1. Differences among bridge, building and tunnel fires.

Bridge fires

Collisions (e.g tanker truck accident)

Ignition of construction materials (e.g.

wooden formwork) during construction.

Ignition of materials stored under the bridge.

For further information see Garlock at al. [4]

and Peris-Sayol et al. [2].

Type of fire and fire development

Fire curves
Hydrocarbon fire (in the most harmful case) with fast heating rates and high fire intensities (see Paya-Zaforteza and Garlock

[12])

The fire is fuel controlled, there is no oxygen limitation.

The heat feedback to the fuel surface in girder bridges depends mainly on the flame volume, the position of the fuel surface and the bridge geometry (see Peris-Sayol et al. [13]).

No specific fire curves available
Building fires

Tunnel fires

Ignition of the materials stored in the building Collisions (e.g. tanker truck accident)

The typical building fire is cellulosic. Thi fire is less intense and results in lower temperatures than a hydrocarbon fire.

The fire can be fuel or ventilation controlled. Flashover can happen.

For further information see Buchanan and Abu [15].
Hydrocarbon fire (in the most harmful case) Tunnel fires can be fuel-controlled (then unreacted air by-passes the burning vehicles), or ventilation-controlled (with large amounts of toxic combustion products or toxic chemical species and incomplete combustion products).

There is a heat feedback to the fuel surface from the surrounding environment which depends on parameters such as flame volume, tunnel lining, tunnel cross sectional area and tunnel ventilation

For further information see Ingason et al. [17]

Nominal fire curves such as the ISO-834 and Fire curves available, such as the modified the ASTM E119 available hydrocarbon HCM, RWS, RABT ZTV. See Parametric fire curves available. See e.g. EC- ITA [18]. 
Table 1 (continued). Comparison of bridge, building and tunnel fires.

\begin{tabular}{|c|c|c|c|}
\hline & Bridge fires & Building fires & Tunnel fires \\
\hline Structural engineering & $\begin{array}{l}\text { As design codes do not specify any fire } \\
\text { resistance for bridges, bridges are not } \\
\text { designed against fires and do not typically } \\
\text { have any type of fire protection. } \\
\text { Bridge span lengths and design loads are } \\
\text { usually much higher than in buildings. } \\
\text { Therefore, bridge steel members are usually } \\
\text { more slender and prone to failure modes not } \\
\text { so critical in buildings, such as web buckling. } \\
\text { (see Paya-Zaforteza and Garlock [12], } \\
\text { Glassman and Garlock [14]) }\end{array}$ & $\begin{array}{l}\text { Design codes specify the fire resistance } \\
\text { required in buildings. Therefore, buildings } \\
\text { are designed against fire hazards and can } \\
\text { have passive and/or active fire protection. }\end{array}$ & $\begin{array}{l}\text { Some guidelines (ITA [18], NFPA [19]) have } \\
\text { proposed design criteria for the fire resistance } \\
\text { of road tunnels. } \\
\text { As fire hazards are commonly considered in } \\
\text { tunnels, they can have passive and/or active } \\
\text { fire protection. }\end{array}$ \\
\hline Design objectives & $\begin{array}{l}\text { Loss of life is not a major issue as fatalities } \\
\text { are usually caused by the collision that started } \\
\text { the fire, not by the bridge collapse or bridge } \\
\text { damage. } \\
\text { The major issue is to ensure the bridge can } \\
\text { continue in operation and so avoid traffic } \\
\text { problems }\end{array}$ & Avoiding life loss is the major objective & Avoiding life loss is the major objective \\
\hline
\end{tabular}




\section{Description of the experimental bridge}

The experimental bridge (see Fig. 1) was divided into three parts:

1) Two abutments built on a leveling slab that placed the lower surface of the deck girders at a height of $1.9 \mathrm{~m}$ above the top face of the leveling slab. This top face was taken as the reference level (level 0 in Fig. 1a) in the project.

2) A composite steel-concrete deck formed by a $0.15 \mathrm{~m}$ thick concrete slab joined by shear studs to two IPE-160 steel girders. The deck was $6 \mathrm{~m}$ long and $2 \mathrm{~m}$ wide. The separation between the axes of the two IPE-160 girders was $1 \mathrm{~m}$, with a $0.5 \mathrm{~m}$ overhang on each side. The girders were supported on the abutments by two unreinforced elastomeric bearings measuring $200 \times 200 \times 20 \mathrm{~mm}$. A composite deck with I-girders was chosen because the analysis of bridge fire events by Peris-Sayol et al. [2] found this to be the most common structural system in bridges that had collapsed or suffered severe damage in fire events.

3) Two auxiliary steel frames used to fix the LVDT sensors used to record the vertical deflections of the deck during the tests.

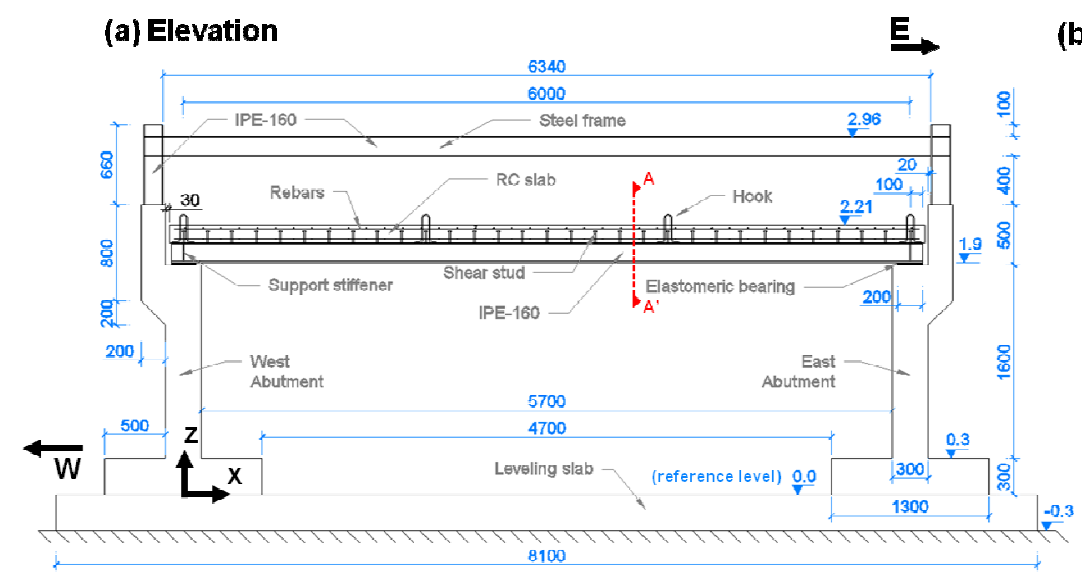

(b) Abutment details

(c) Deck details (Section AA')

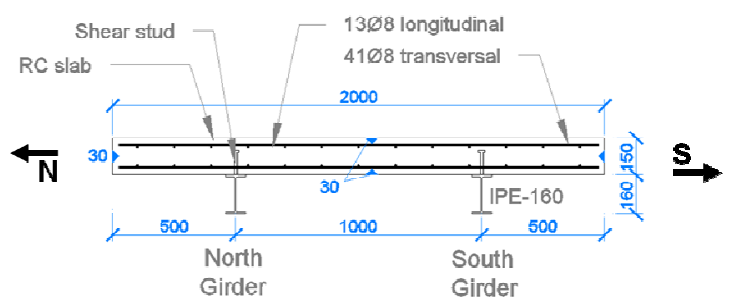

Figure 1. Experimental bridge: (a) Elevation, (b) Abutment details and (c) Deck details. All the dimensions are expressed in $\mathrm{mm}$. All the levels ( $\mathrm{z}$ coordinates) are expressed in $\mathrm{m}$. 
Alos-Moya J., Paya-Zaforteza I., Hospitaler A., Rinaudo P.

Valencia bridge fire tests: Experimental study of a composite bridge under fire (2017) Journal of Constructional Steel Research, 138, pp. 538-554. DOI: 10.1016/j.jcsr.2017.08.008

Both the deck girders and the auxiliary frames were of S355JR steel. The deck slab and abutments were designed with a characteristic compressive strength obtained from cylindrical specimens at 28 days of 25 and $30 \mathrm{MPa}$, respectively. The reinforcing steel was B500S with $500 \mathrm{MPa}$ as characteristic yield strength. Section 2.5 contains further details on the mechanical properties of the materials used to build the bridge.

Regarding the design of the experimental bridge, it is important to note that:

- The structural system tested is commonly used in short and medium span highway structures (Taly [29] and Llago and García [30]). This system is different to the typical composite floors used in buildings (see e.g. Taranath [31]), in which the concrete slab is supported by a steel deck anchored or welded to the I-girders.

- The bridge I-girders do not have any fire protection because bridges are not usually designed against fire hazards and therefore their steel elements are unprotected.

- The bridge was not designed as a replica or reduced scale model of a specific bridge. The guiding principle of the bridge design and the experiments was to enable the study of some important aspects that previous studies [2,3,13,23-25] on bridge fires had highlighted, such as: (1) the impingement of the flames on the bridge deck, (2) the spread of flames, heat and smoke between two adjacent bridge girders, (3) the creation of significant longitudinal thermal gradients along the bridge girders and (4) the influence of the fire load position on gas and bridge temperatures.

- The experimental bridge was designed without transverse diaphragms between the two girders, despite the fact that they are often found in real bridges. These elements could block the longitudinal flow of hot gases between two adjacent girders during a fire event and thus influence the temperatures of the gases around the structure. However, the authors considered that this influence would be small because: (a) the diaphragm depth is typically much smaller than the main girder depth (see e.g. the bridge analyzed in [12]) and (b) sometimes (see e.g. the bridge analyzed in [23]), the diaphragm is a truss structure and therefore is almost transparent to the flow of hot gases.

\subsection{Construction process}

The bridge was constructed in the following steps (see Fig. 2):

Step 1: Placing the formwork and pouring the concrete of the leveling slab to create a horizontal surface upon which to build the foundations of the bridge abutments. 
Step 2: Erection of formwork and pouring of concrete for the abutments footings.

Step 3: Erection of formwork and pouring of concrete for the abutments walls. The abutments support both the deck under study and the steel frames used to measure the deflections.

Step 4: Placing girders and auxiliary frames.

Step 5: Placing the deck slab formwork supported by shores.

Step 6: Drilling small holes in six rebars of the lower longitudinal deck reinforcement and in three connecting bolts for the thermocouples.

Step 7: Placement of deck reinforcement with a concrete cover of $30 \mathrm{~mm}$.

Step 8: Placing of nine thermocouples (TCs) to measure temperatures in rebars (6 TCs) and shear studs (3 TCs), and protecting the thermocouple connections to avoid damage while pouring the deck concrete. Placing conduits and auxiliary hooks for the thermocouples used to measure gas temperatures around the bridge and steel girders.

Step 9: Pouring and curing deck concrete.

Step 10: Removal of formwork and shores from the deck 50 days after concrete pouring. 


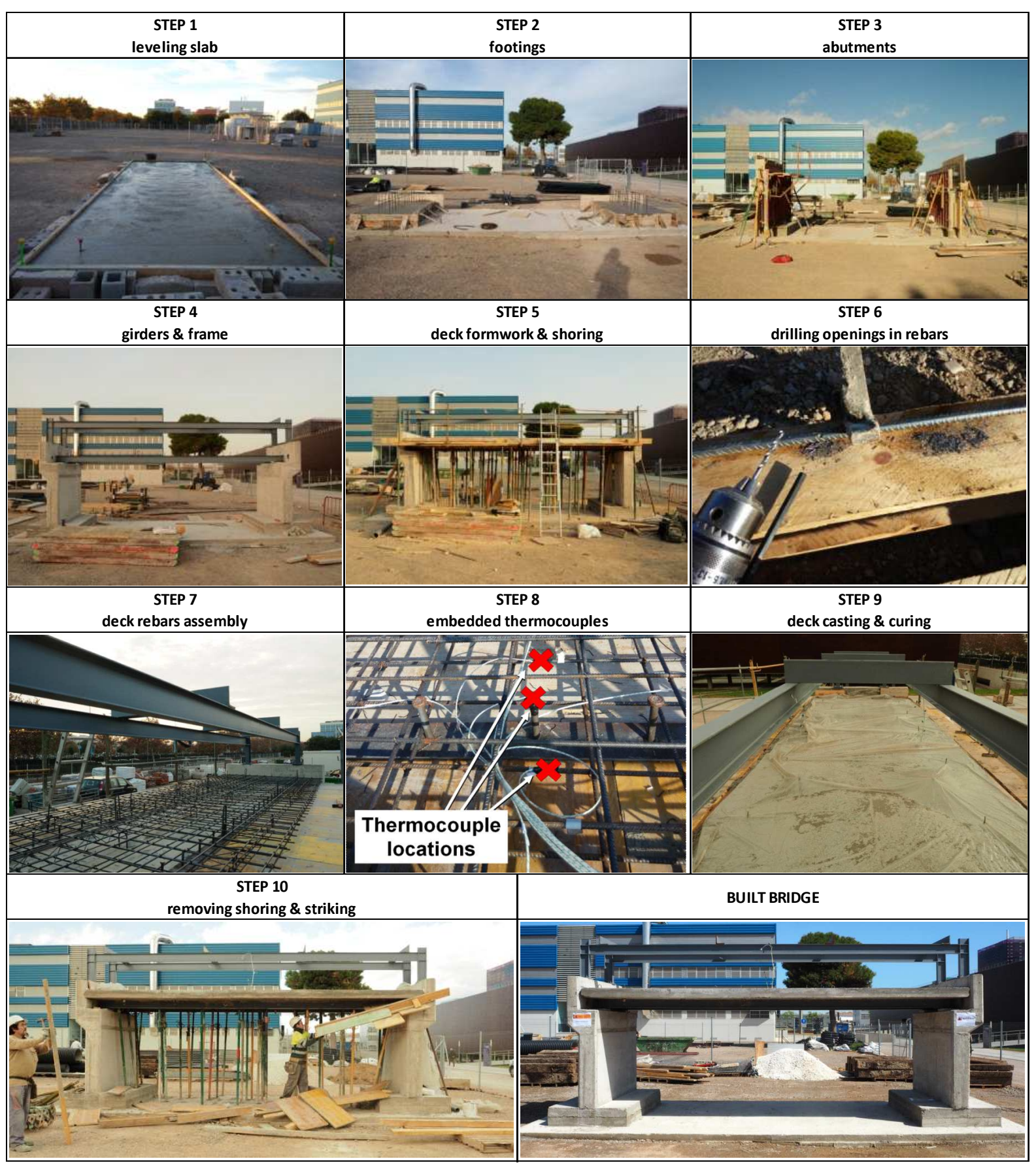

Figure 2. Construction process of the experimental bridge.

\subsection{Fire Scenarios}

\subsubsection{Preliminary tests.}

Before carrying out the tests on the bridge itself, a series of preliminary tests were performed with the following aims:

- To characterize the fire loads under the bridge before the actual tests. 
- To confirm whether or not the gasoline could be ignited with safety.

- To ensure that the protection of the weighing scale used to measure mass loss rate (see Section 2.3.1) would keep the scale temperature below $40^{\circ} \mathrm{C}$.

After these tests (Fig. 3) the following conclusions were drawn:

- Winds above $2 \mathrm{~m} / \mathrm{s}$ strongly deflect flames (see Fig. 3b) and considerably distort the results achieved with no wind. For this reason, all the tests on the bridge were carried out with winds below this figure and a $2 \mathrm{~m}$ high fence was built around the site to reduce the effects of gusts during the tests.

- The pans of fuel should only be ignited by the local Fire Department to guarantee the safety of personnel and equipment. Since gasoline gives off inflammable gases at ambient temperatures, the tests should begin immediately after pouring the gasoline into the pans.

- The scale was adequately protected since the recorded temperatures were always lower than $40^{\circ} \mathrm{C}$.

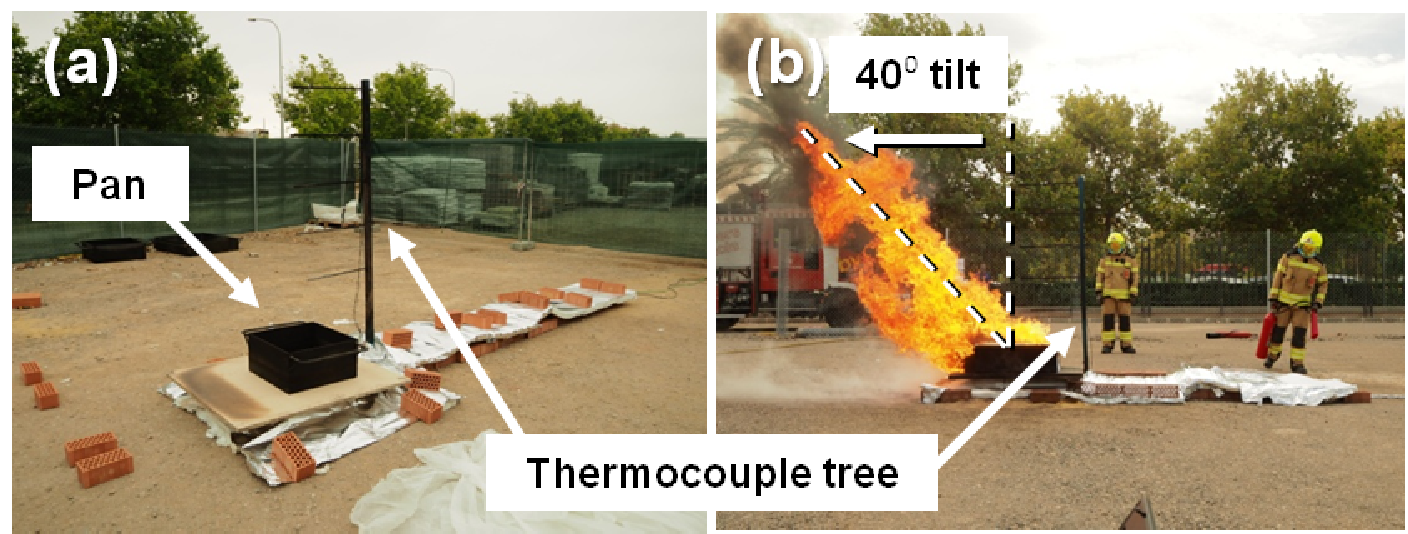

Figure 3. Preliminary tests: (a) Elements. (b) View of one of the tests.

\subsubsection{Bridge fire scenarios.}

The experimental bridge was subjected to eight fire tests in four different scenarios involving different magnitudes and fire load positions (see Table 2 and Fig. 4). The fire load was always located under the bridge because the statistical analysis of bridge fires by PerisSayol et al. [2] shows that fires caused by tanker trucks cause the most damage and the most serious accidents are those in which the tanker is either immediately under the bridge or actually on the bridge but with significant oil spillage under the bridge. 
Given the differences between bridge, building and tunnel fires (see Table 1) the fire tests used to study them should be different. In this sense, the present study differs from previous experimental work with composite floor slabs typically used in buildings (see e.g. Nadjai et al. [32], Li et al. [33], Baley and Toh [34]) as follows: (a) the general features of the structural system tested, (b) the use of gasoline as fire load, (c) the bridge tested was submitted to considerable longitudinal thermal gradients and was not uniformly heated along its length, (d) the Valencia bridge fire tests were carried out in the open air and not in a furnace or compartment.

Fire load magnitude is defined by the Heat Release Rate (HRR). As the Valencia bridge fire tests involved gasoline in two square pans, one with a side of $0.5 \mathrm{~m}$ and the other one with a side of $0.75 \mathrm{~m}$, according to Drysdale [35] the expected power corrected for the size effect was 415 and $1131 \mathrm{~kW}$, respectively.

The fire load position is defined by:

- The level ("z" coordinate) of the base of the pan containing gasoline, which varied between $0.2,0.5$ and $0.8 \mathrm{~m}$.

- The " $x$ " coordinate (see Fig. 1) at the center of the fuel pan, which could have values of $3.00,5.27$ and $5.59 \mathrm{~m}$, according to whether the pan was placed at the center or near to the East abutment (see Table 2).

\begin{tabular}{|c|c|c|c|c|c|c|c|c|}
\hline \multirow{2}{*}{$\begin{array}{c}\text { Fire } \\
\text { scenario }\end{array}$} & \multirow{2}{*}{$\begin{array}{l}\text { Pan } \\
\text { side } \\
s(\mathrm{~m}) \\
\end{array}$} & \multirow{2}{*}{$\begin{array}{c}\text { Fire } \\
\text { location }\end{array}$} & \multirow{2}{*}{ HRR $(\mathrm{kW})$} & \multirow{2}{*}{ Test } & \multirow{2}{*}{$\begin{array}{c}\text { Protection } \\
\text { board } \\
\end{array}$} & \multirow{2}{*}{$\begin{array}{c}\text { Distance to } \\
\text { East Abutment (m) }\end{array}$} & \multicolumn{2}{|c|}{ Pan location } \\
\hline & & & & & & & $\mathrm{x}(\mathrm{m})$ & $z(\mathrm{~m})$ \\
\hline \multirow{2}{*}{ Fire 1} & \multirow{2}{*}{0.5} & \multirow{2}{*}{ Mid-span } & \multirow{2}{*}{415} & 1 & no & - & \multirow{2}{*}{3.00} & \multirow{2}{*}{0.2} \\
\hline & & & & 2 & no & - & & \\
\hline \multirow{2}{*}{ Fire 2} & \multirow{2}{*}{0.75} & \multirow{2}{*}{ Mid-span } & \multirow{2}{*}{1131} & 3 & no & - & \multirow{2}{*}{3.00} & \multirow{2}{*}{0.2} \\
\hline & & & & 4 & no & - & & \\
\hline \multirow{3}{*}{ Fire 3} & \multirow{3}{*}{0.5} & \multirow{3}{*}{ Lateral } & \multirow{3}{*}{415} & 5 & $1.65 \mathrm{~m}$ East & 0.33 & 5.27 & \multirow{3}{*}{0.5} \\
\hline & & & & 6 & $1.65 \mathrm{~m}$ East & 0.01 & 5.59 & \\
\hline & & & & 7 & no & 0.01 & 5.59 & \\
\hline Fire 4 & 0.75 & Mid-span & 1131 & 8 & no & - & 3.00 & 0.8 \\
\hline
\end{tabular}

Table 2. Valencia bridge fire tests. Fire scenarios.

The following circumstances should be noted:

- The fire load magnitudes in the experiments are smaller than the fire load of a typical tanker truck carrying gasoline. If the tanker surface is assumed to be $30 \mathrm{~m}^{2}(12 \times 2.5$ $\mathrm{m}$ ) and a HRR per Unit of Area of $2400 \mathrm{~kW} / \mathrm{m}^{2}$ is considered according to 
Babrauskas [36], then the resulting HRR is $72 \mathrm{MW}$. Although there is a big difference in the HRR absolute value, it is not so relevant when the following circumstances are considered: (1) the research goals of the experimental campaign required several tests with the fire under the bridge but without the bridge suffering any major damage, (2) the temperatures in the steel girders in Test 8 were similar to those of real fire events, as explained in Section 3.2.3, (3) As Fig. 4 shows, the fire load in the tests was high enough to make the flames impinge on the deck, as usually happens in tanker truck fires under bridges, (4) economic, environmental and safety concerns ruled out the fire loads involved in a typical tanker truck accident.

- Due to the influence of the wind on the fire, two tests were performed for each of the Fire 1 and Fire 2 scenarios.

- Fire 3 scenario was carried out to check the influence of (a) the abutments on the effects of the fire, with three tests at different distances between the edge of the pan and the abutment $(0.33$ or $0.01 \mathrm{~m})$ and $(\mathrm{b})$ the presence of an insulating board that partially protected the deck.

- Test 8 involved the $0.75 \mathrm{~m}$ pan at $0.5 \mathrm{~m}$ higher than in Tests 3 and 4 , with the aims of subjecting the bridge to more intense thermal exposure, and obtaining a thermomechanical response closer to that found in previously studied accidents $[23,26,37]$. 


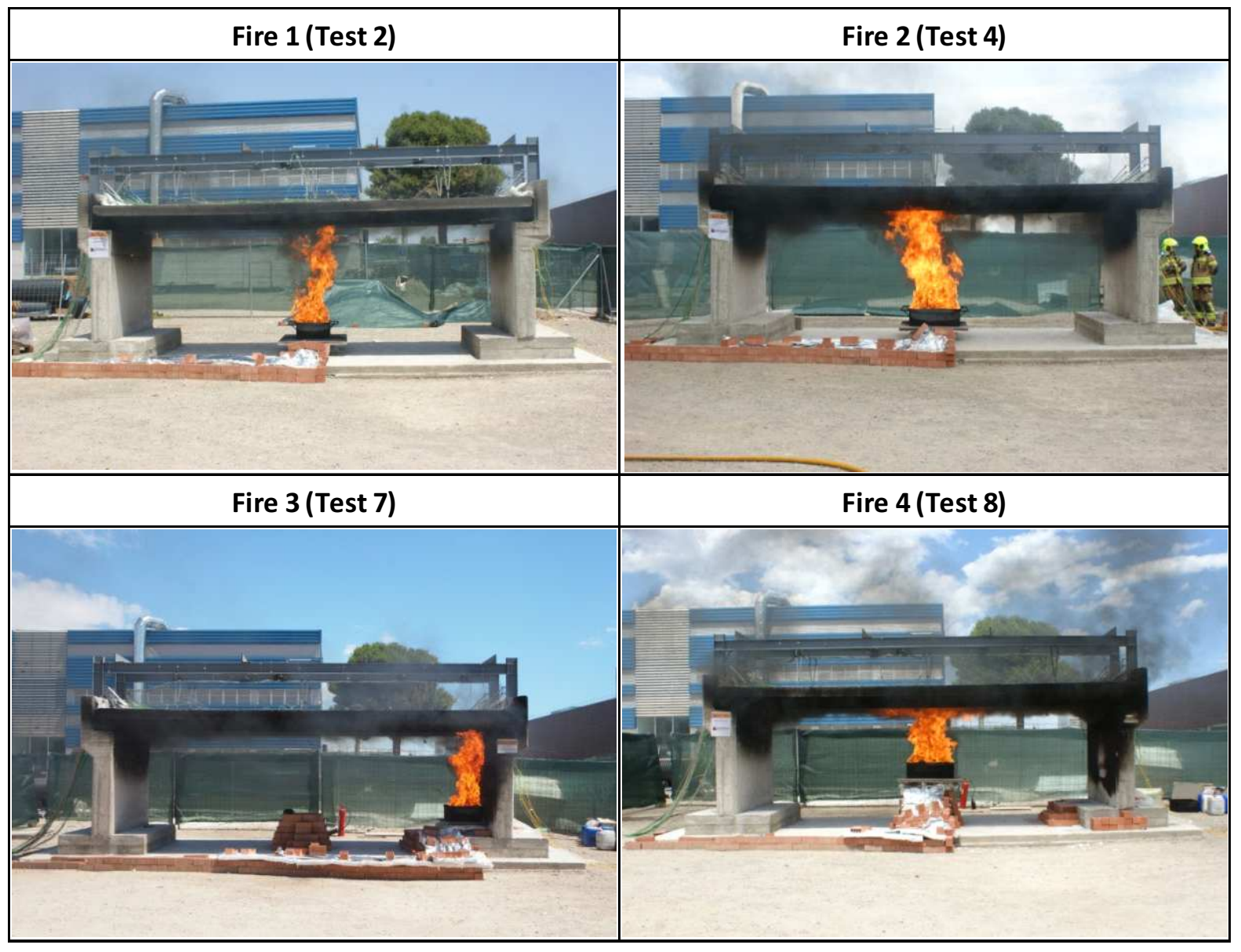

Figure 4. Views of fire tests corresponding to each fire scenario.

\subsection{Instrumentation}

During the tests three variables were continuously recorded: weight of fuel, gas surrounding the deck and deck temperatures, and vertical deflections at various points of the deck, by means of a weight scale, 72 thermocouples (TCs) and 22 LVDTs, as well as 17 high temperature fiber optic sensors. Additional information is given below on the location and installation of the monitoring systems.

\subsubsection{Scale}

An industrial PCE-SD $300 \mathrm{C}$ scale able to weigh up to $300 \mathrm{~kg}$ to an accuracy of within $100 \mathrm{~g}$ was used to measure mass loss rate during the tests. Since it could only resist up to $40^{\circ} \mathrm{C}$ it had to be protected by a fire blanket with incombustible alkaline earth silicate panels (see Fig. 5), which also protected the cable that transmitted the signal from the scale through the zone of highest thermal exposure. Bricks were also used to protect the cable and scales and raise the scale to the appropriate level in each fire test. Radiant heat was mitigated by aluminum foil. During the tests two thermocouples were used to ensure that temperatures in the load cell and scale computer did not exceed $40^{\circ} \mathrm{C}$. 


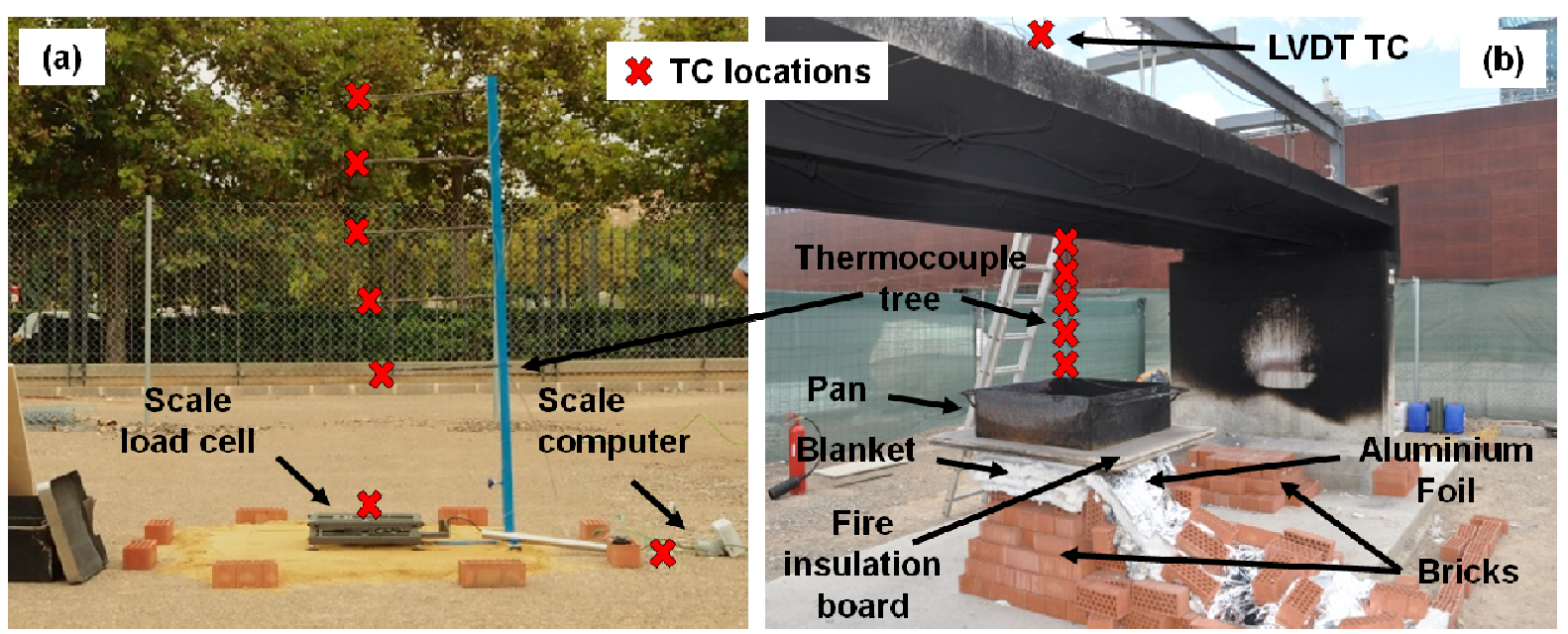

Figure 5. (a) Scale before placing protection for a preliminary test. (b) Scale protection with insulation blanket, insulation boards, bricks and aluminum foil.

\subsubsection{Thermocouples}

A total of 72 Type-K thermocouples were installed to measure temperatures, four of which recorded the temperature in the scale and over the deck, 23 measured gas temperatures around the bridge, 28 in the steel deck girders, 3 in the shear studs, and 6 in the rebars. A reference thermocouple was also used to record ambient temperatures. Seven thermocouples were used to check the correct operation of the high-temperature fiber optic sensors. Table 3 gives the main characteristics of the thermocouples used (see Sections 2.3.2.1 to 2.3.2.4 for further details). 


\begin{tabular}{|c|c|c|c|c|}
\hline Measurement & Distribution & Thermocouple location & Number of TCs & Name of TC \\
\hline Scale control & see Fig. 5a & under the isolation materials & 2 & SCALE1, SCALE2 \\
\hline LVDT control & see Fig. $5 b$ & over the deck & 2 & LVDT1, LVDT2 \\
\hline \multirow{4}{*}{ Gas } & \multirow{4}{*}{ see Fig. 6} & vertical thermocouple tree & 5 & V1 to V5 \\
\hline & & South region & 6 & GS1 to GS6 \\
\hline & & Central region & 6 & GC1 to GC6 \\
\hline & & North region & 6 & GN1 to GN6 \\
\hline \multirow{6}{*}{ Steel } & \multirow{6}{*}{ see Fig. 7} & South girder - bottom flange & 6 & SG-BF1 to SG-BF6 \\
\hline & & South girder - web & 2 & SG-W1 to SG-W6 \\
\hline & & South girder - top flange & 6 & SG-TF1 to SG-TF6 \\
\hline & & North girder - bottom flange & 6 & NG-BF1 to NG-BF6 \\
\hline & & North girder - web & 2 & NG-W1 to NG-W6 \\
\hline & & North girder - top flange & 6 & NG-TF1 to NG-TF6 \\
\hline \multirow{2}{*}{ Slab } & \multirow{2}{*}{ see Fig. 8} & rebars at mid-span & 6 & RB1 to RB6 \\
\hline & & shear studs at mid-span & 3 & $\mathrm{SS} 1$ to SS3 \\
\hline $\begin{array}{c}\text { Fiber optic } \\
\text { sensor control }\end{array}$ & - & near the fiber optic sensors & 7 & TC-1 to TC-7 \\
\hline Reference & see Fig. 10 & on the monitoring table & 1 & REF \\
\hline
\end{tabular}

Table 3. Thermocouple distribution.

\subsubsection{Control thermocouples}

A reference TC was used to measure ambient temperatures, two to check that the scale temperature remained below $40^{\circ} \mathrm{C}$ and two others to monitor temperatures around the LVTDs.

\subsubsection{Gas thermocouples}

Twenty-three TCs arranged on 7 thermocouple trees (TCTs) were used to characterize the thermal field around the lower deck face: six were placed horizontally at $2.00 \mathrm{~m}$ above the reference level in the positions shown in Fig. 6 , and a seventh was placed vertically over the fuel pan (also shown in Fig.6). Table 4 gives the " $x$ " and " $z$ " coordinates of the TCs of the vertical tree, identified as $\mathrm{V} 1$ to $\mathrm{V} 5$, with $\mathrm{V} 1$ nearest to the pan and V5 furthest away. The nomenclature of a thermocouple belonging to a horizontal TCT was in three characters: the first being " $G$ " as it measured gas temperatures, and the second could be "N", "C" or " $S$ ", according to whether it was in the North, Central or South region of the gas surrounding the deck (Fig. 6b). The third character varied between 1 and 6, according to the TC's longitudinal position (Sections S1 to S6 in Fig. 6a) 
(a) Elevation

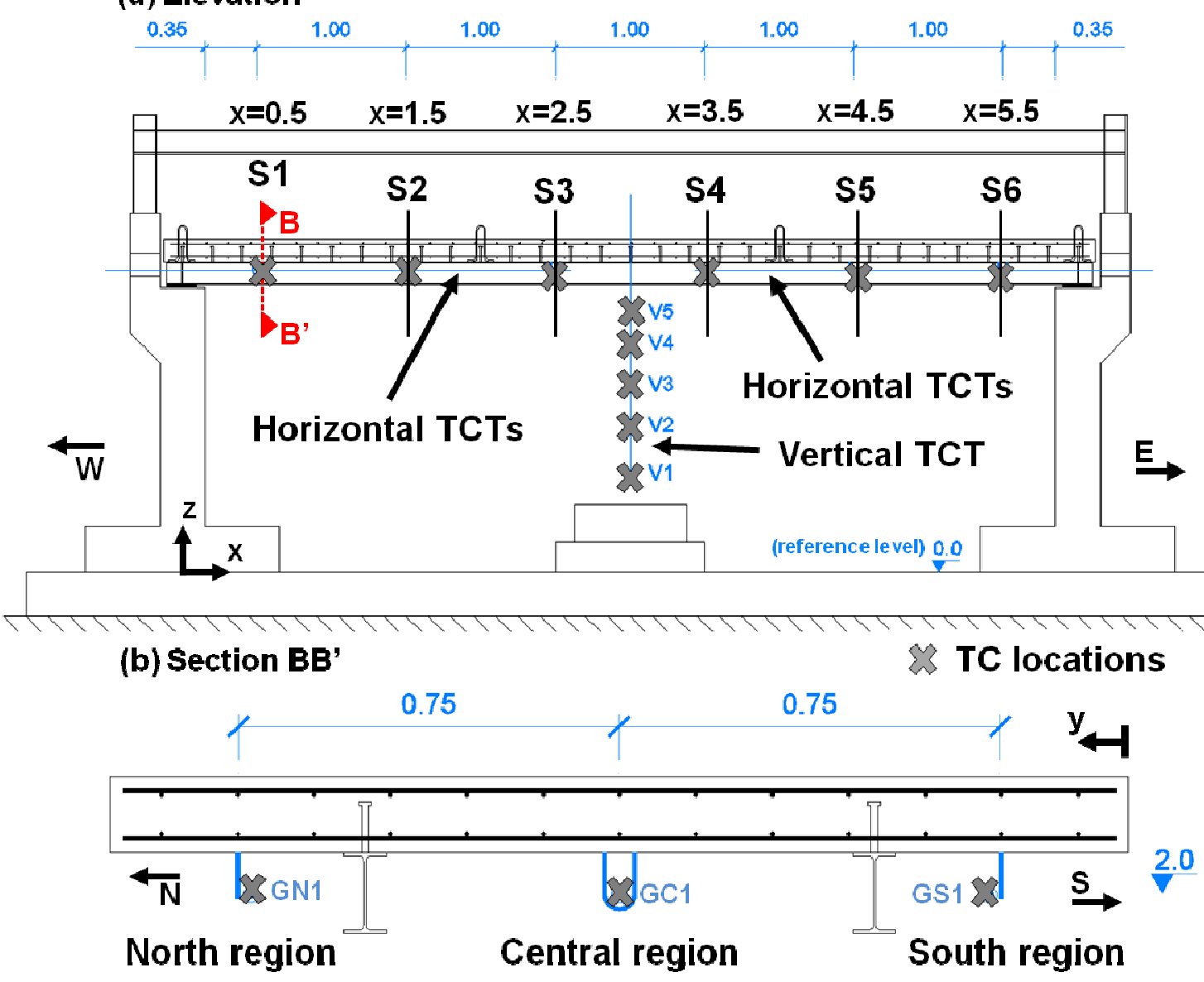

Figure 6. Gas thermocouple distribution. All dimensions are given in $\mathrm{m}$.

\begin{tabular}{cccc}
\hline \multirow{2}{*}{ TC name } & \multicolumn{3}{c}{ z coordinate (m) } \\
& Fire 1 \& 2 & Fire 3 & Fire 4 \\
\hline V5 & 1.73 & 1.95 & 1.89 \\
V4 & 1.54 & 1.69 & 1.73 \\
V3 & 1.24 & 1.41 & 1.54 \\
V2 & 0.99 & 1.13 & 1.44 \\
V1 & 0.65 & 0.85 & 1.25 \\
\hline
\end{tabular}

Table 4. Location of thermocouples in the vertical TCT.

\subsubsection{Steel thermocouples}

The 28 TCs installed in the girders were attached at the same transversal sections as those used to measure gas temperatures in order to acquire gas exposure temperatures and steel temperatures on both sides of the girders. The TCs were symmetrically distributed on both girders in two types of section (see Fig. 7). 
- Type A Section (SA in Fig. 7a). This section had three TCs in each monitored girder section. The sensors were placed on the web mid-point at the intersection of the top and bottom flanges with the web (see Fig. 7b).

- Type B Sections (SB in Fig. 7a) with two TCs in each section placed on the web midpoint at the intersection of the bottom flange with the web of each girder (see Fig. 7c).

The nomenclature of the TCs placed on the steel has three parts: the first two characters identify the girder (SG: South Girder, NG: North Girder) while the position is indicated by one or two additional characters (BF: Bottom Flange, W: Web, TF: Top Flange) plus the section number (1 to 6$)$.

(a) Elevation

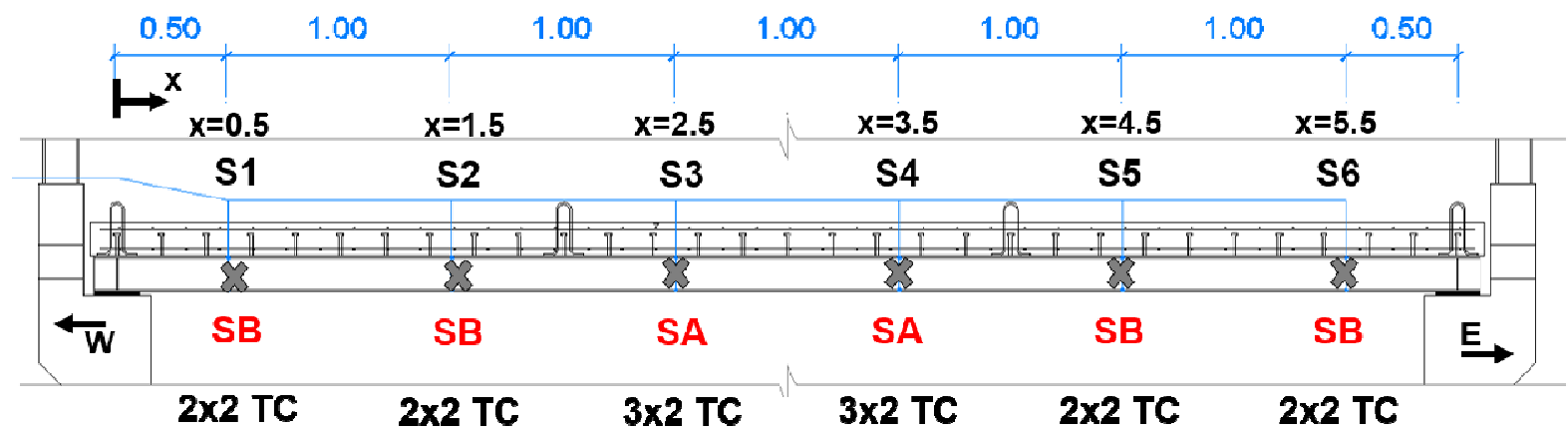

(b) Section Type A

(c) Section Type B

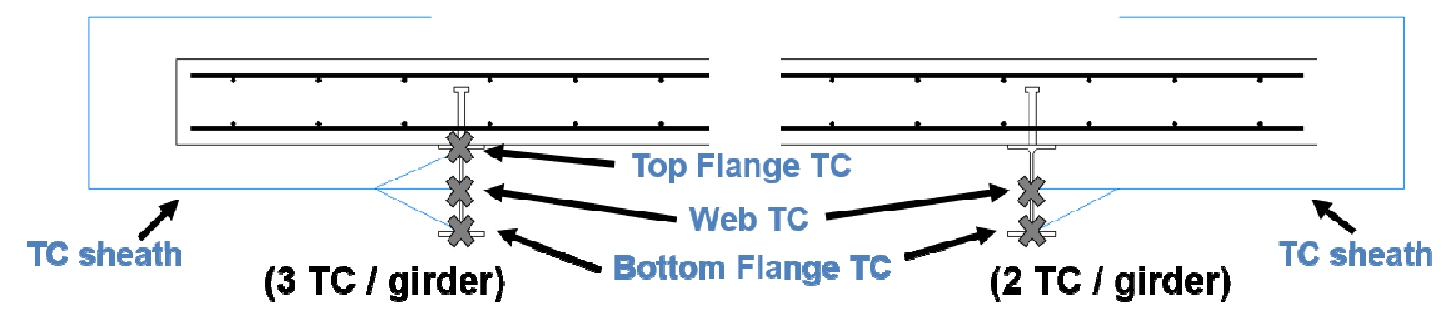

Figure 7. Steel thermocouple distribution. All dimensions are given in $\mathrm{m}$. 
Valencia bridge fire tests: Experimental study of a composite bridge under fire (2017) Journal of Constructional Steel Research, 138, pp. 538-554. DOI: 10.1016/j.jcsr.2017.08.008

\subsubsection{Concrete thermocouples}

Six of the nine TCs embedded in the concrete monitored temperatures in the longitudinal reinforcement rebars (TCs RB1 to RB6 in Fig. 8) and were placed in the section with $x=$ $3.00 \mathrm{~m}$. Transversal separation varied (see Fig.8b), with four TCs between the two girders (RB2, RB3, RB4, RB5) and two (RB1 and RB6) located in the slab overhangs.

TCs SS1, SS2 and SS3 were in contact with the heads of three shear studs at $10 \mathrm{~cm}$ above the top flanges of the IPE-160 girders (see Fig. 8).

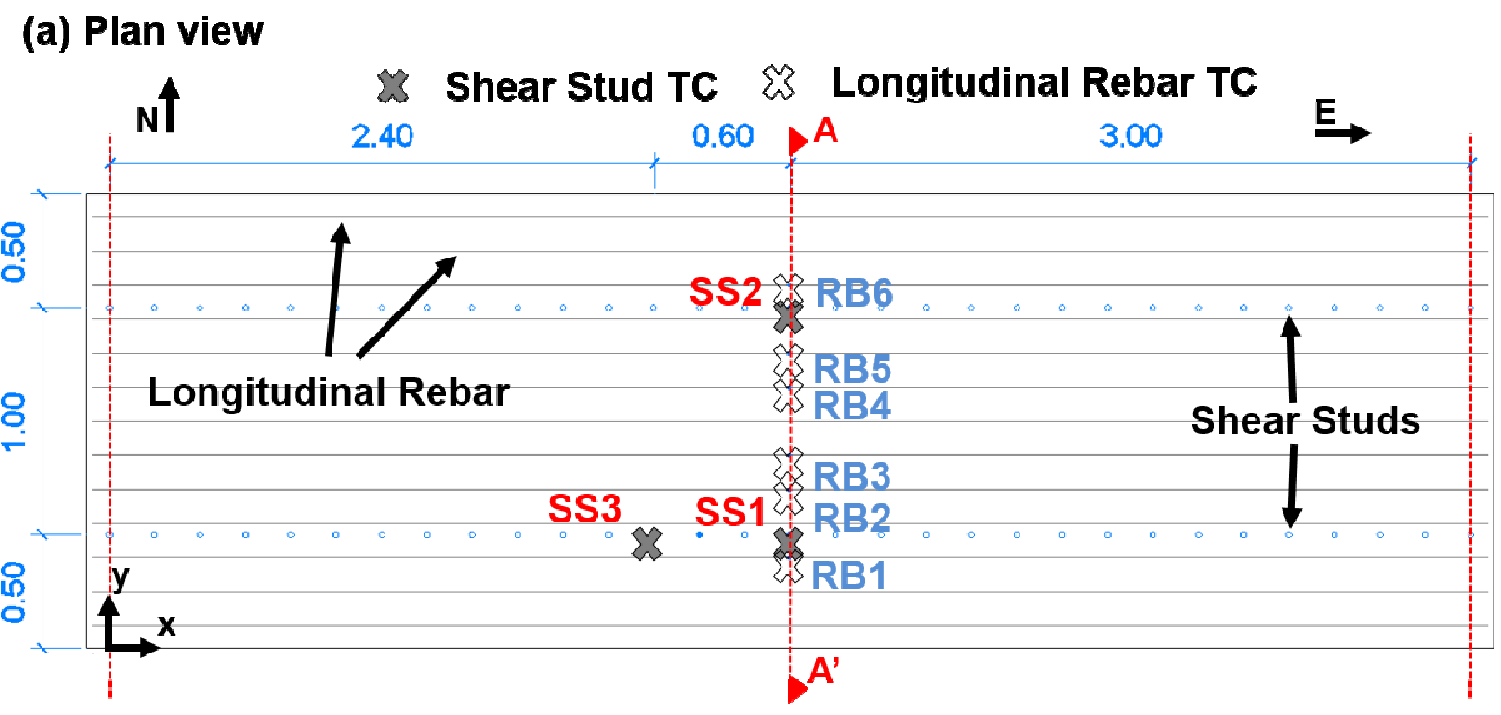

(b) Section AA'

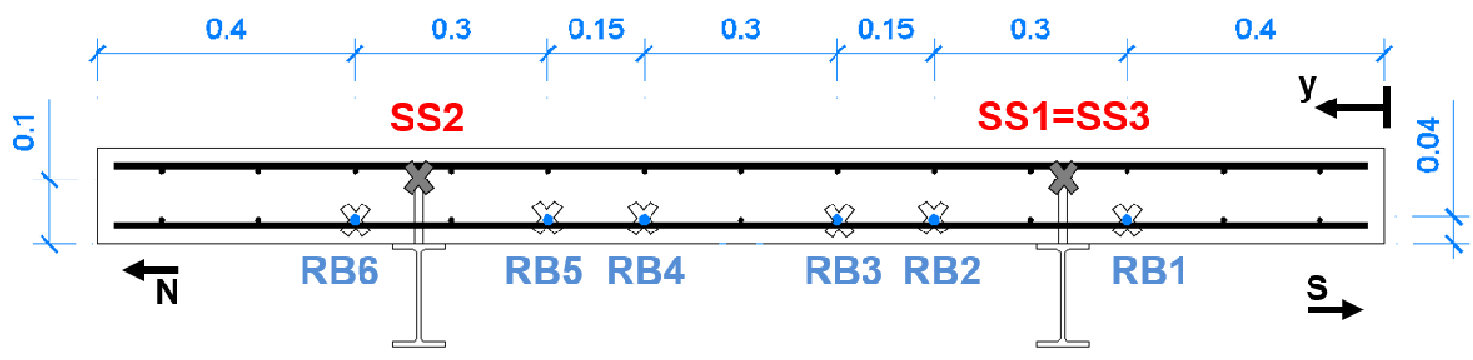

Figure 8. RC slab thermocouple locations. All dimensions are given in $\mathrm{m}$. 


\subsection{3. $L V D T$}

Deck deflections were monitored by twenty-two $300 \mathrm{~mm}$ range LVDTs arranged as follows (Fig. 9):

- Two LVDTs (L21 and L22) were placed on the auxiliary steel frames to detect length increments in the frames due to thermal expansions due to the temperature reached during the tests.

- Eight LVDTs (L1, L2, L3, L4, L17, L18, L19, L20) measured horizontal deck movements at the expansion joints.

- Twelve LVDTs (L5, L6, L7, L8, L9, L10, L11, L12, L13, L14, L15, L16) were arranged in pairs in V-formation along three sections on each girder to record deflection evolution in order to obtain duplicate readings at all six points during the tests and to measure horizontal displacements.

\section{(a) North Frame elevation}

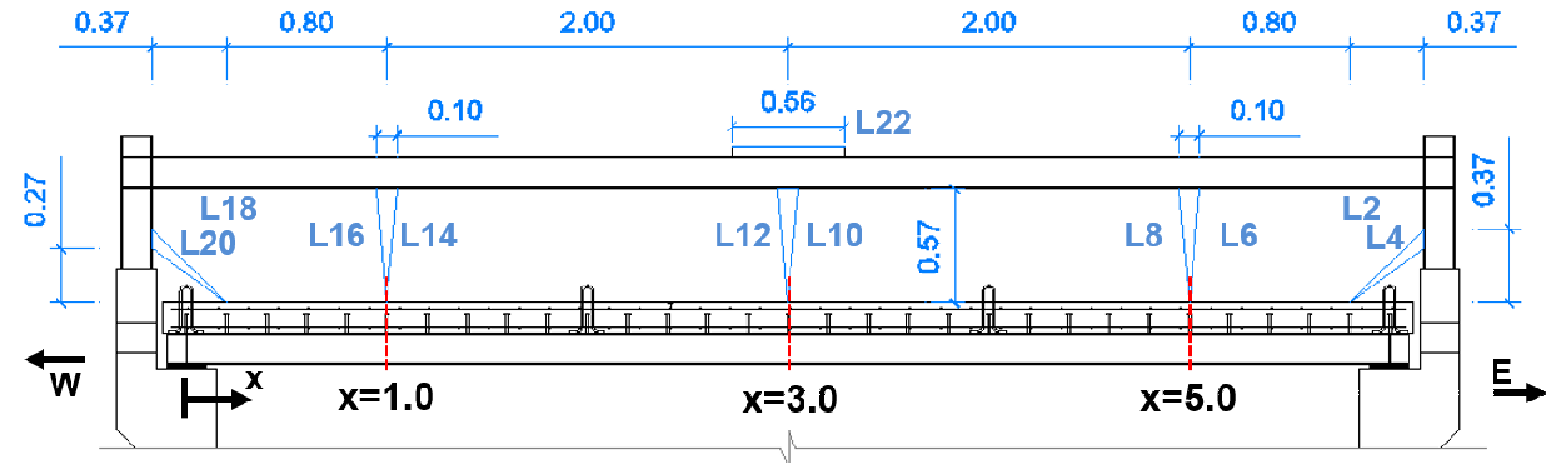

\section{(b) South Frame elevation}

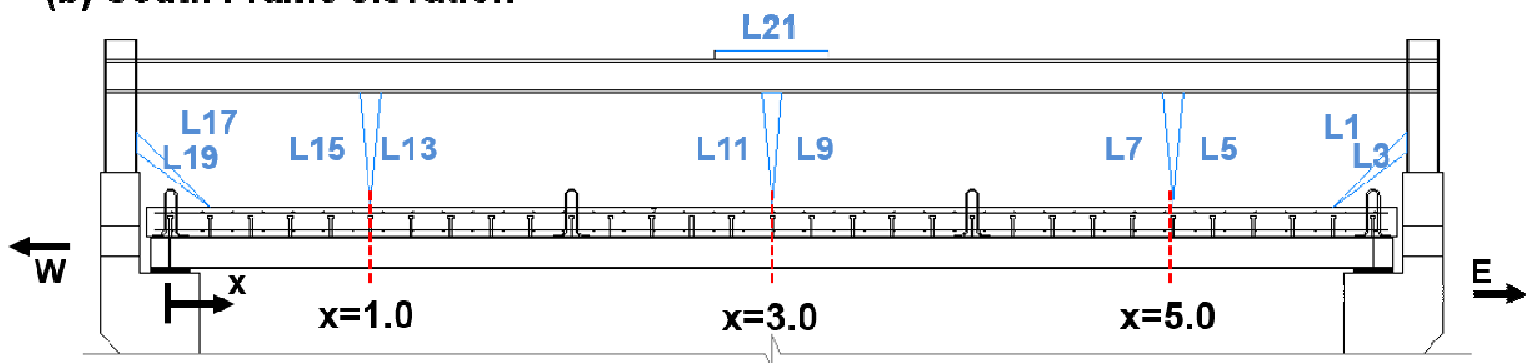

Figure 9. LVDT distribution, All dimensions are given in $\mathrm{m}$.

\subsubsection{High temperature fiber optic sensors.}

A series of high temperature sensors were installed to measure concrete, gas, and steel temperatures. These sensors were similar to those developed by Rinaudo et al. [38, 39] and were placed in the following locations: 
- Two multiplexed sensors were located at the mid-span section embedded in the concrete slab and measured concrete temperatures. Each sensor had three Fiber Bragg Gratings (FBGs) and measured temperatures at three different locations.

- One multiplexed sensor was located at Section S3 (see Fig. 6), $0.5 \mathrm{~m}$ away from the mid-span bridge section. This sensor had two Regenerated Fiber Bragg Gratings (RFBGs henceforth) and measured gas temperatures at two different points, located 5 and $10 \mathrm{~cm}$ away from the RC slab bottom face.

- One multiplexed sensor was located at Section S2 (see Fig. 6), located 1.5 m away from the mid-span bridge section. This sensor had three RFBGs and measured gas temperatures at three different points, located 5,9 and $13 \mathrm{~cm}$ away from the RC slab bottom face.

- Two sensors each one having a single RFBG were located at the junction of the bottom flange and the web of each steel girder. The sensors were $1.5 \mathrm{~m}$ away from the East abutment and measured steel temperatures.

- Two multiplexed sensors with two RFBGs per sensor were located at the junction of the bottom flange and the web of each steel girder. Each one of these two sensors measured temperatures at points located 1.5 and $2 \mathrm{~m}$ away from the East abutment.

The goal of installing fiber optic sensors was to test their operation under actual fire conditions. These sensors were installed as a redundant monitoring, they were not necessary to investigate the experimental response of the bridge during the fire tests. A detailed analysis of their behavior is the object of future research.

\subsection{Data recording}

Three different data acquisition systems were used for TCs, LVDTs and fiber optic temperature sensors. These readings were stored in separate computers due to the large quantities of data involved. Temperatures recorded by the TCs were registered by nine modules of eight channels: seven "USB TC-08" modules and two "FP-TC-120". The displacements detected by the LVDTs were recorded by a single 32-channel cDaq-9205 module. The temperature readings from the USB TC-08 modules could be monitored during the test by means of the Picolog software in the USB TC-08 modules, while the rest of the readings could be visualized by the CEAD $11.36 \mathrm{~L}$ software developed by ICITECH personnel. 

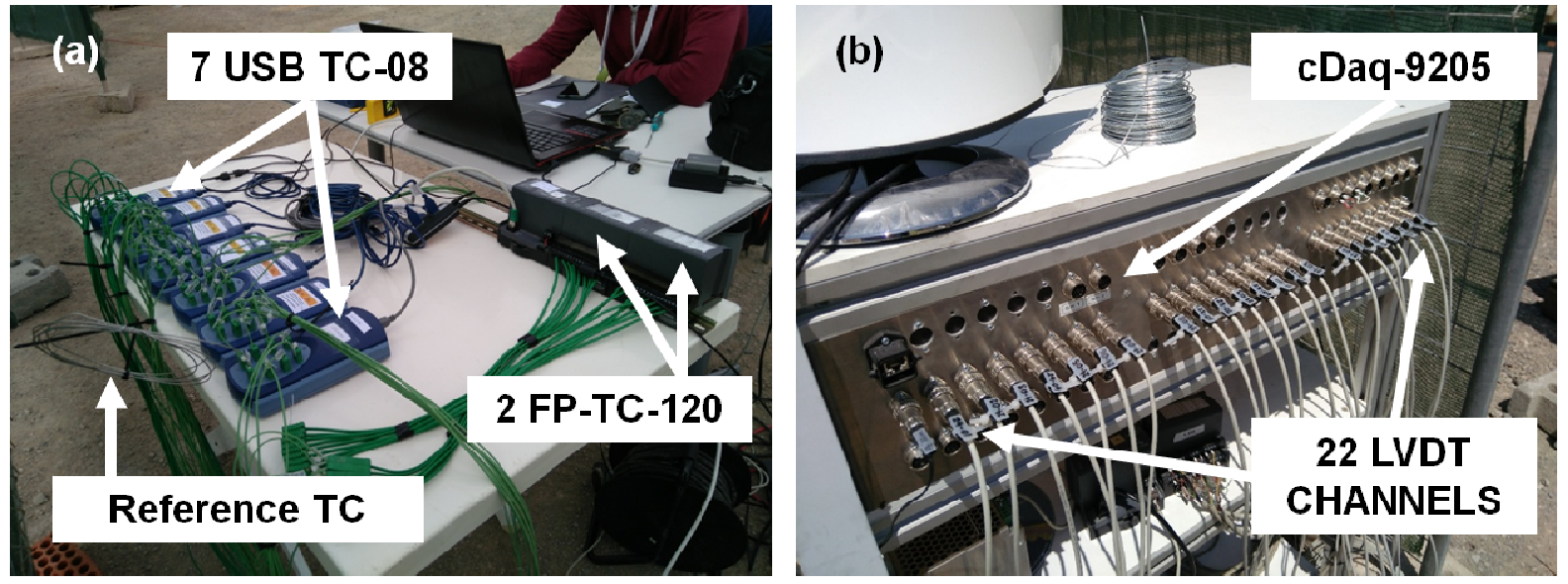

Figure 10. (a) Nine 8-channel thermocouple dataloggers and (b) 22 LVDTs extensions connected to the 32-channel data acquisition module

\subsection{Laboratory tests}

Four cylindrical $15 \mathrm{~cm}$ diameter x $30 \mathrm{~cm}$ long deck concrete specimens were obtained. These were kept close to the deck so as to undergo the same ambient conditions. The tests on the specimens provided a mean compressive strength of $33 \mathrm{MPa}$ as well as a mean modulus of elasticity of $33.8 \mathrm{GPa}$.

Four specimens from the web and four from the IPE-160 flanges from the batch to which the deck girders belonged were subjected to tensile tests, obtaining elastic limits of 377 and 344 $\mathrm{MPa}$ and yield strengths of 512 and $465 \mathrm{MPa}$ in flange and webs, respectively.

Four $8 \mathrm{~mm}$ diameter rebars and three $12 \mathrm{~mm}$ diameter rebars from the B500S steel batch used for the deck slab reinforcement were traction tested, obtaining a mean elastic limit of 546 and $537 \mathrm{MPa}$ and a mean yield strength of 644 and $624 \mathrm{MPa}$ for $8 \mathrm{~mm}$ diameter rebars and $12 \mathrm{~mm}$ diameter rebars, respectively. 


\section{Results and discussion}

\subsection{Mass loss rate}

Table 5 compares the mass loss per surface unit obtained experimentally with the theoretical mass loss per unit according to [36]. The table includes the mass loss rate obtained experimentally without the existence of the bridge (see Section 2.2.1) in order to verify whether the bridge had an influence on this value. It can be seen that the experimental values oscillate between 0.030 and $0.043 \mathrm{~kg} / \mathrm{m}^{2} \mathrm{~s}$ for the $50 \mathrm{~cm}$ pan with a theoretical value of $0.038 \mathrm{~kg} / \mathrm{m}^{2} \mathrm{~s}$, while for the $75 \mathrm{~cm}$ pan the experimental values are between 0.046 and $0.055 \mathrm{~kg} / \mathrm{m}^{2} \mathrm{~s}$ with a reference theoretical value of $0.046 \mathrm{~kg} / \mathrm{m}^{2} \mathrm{~s}$. Figure 11 shows the curves from which Table 5 was obtained and compares them with the theoretical values represented by the dotted lines.

\begin{tabular}{cccc}
\hline Test & \multicolumn{2}{c}{ Mass loss rate $\mathbf{( k g / \mathbf { m } ^ { 2 } \mathbf { s } )}$} & $\mathbf{( \% )}$ \\
& experimental & theoretical & difference \\
\hline Preliminary 50 & 0.037 & 0.038 & $-2.5 \%$ \\
Test 1 & 0.043 & 0.038 & $13.3 \%$ \\
Test 2 & 0.039 & 0.038 & $1.5 \%$ \\
Test 5 & 0.041 & 0.038 & $8.5 \%$ \\
Test 6 & 0.030 & 0.038 & $-22.3 \%$ \\
Test 7 & 0.033 & 0.038 & $-12.3 \%$ \\
\hline Preliminary 75 & 0.050 & 0.046 & $8.6 \%$ \\
Test 3 & 0.052 & 0.046 & $13.9 \%$ \\
Test 4 & 0.046 & 0.046 & $0.9 \%$ \\
Test 8 & 0.055 & 0.046 & $18.7 \%$ \\
\hline Average 50 (six tests) & 0.037 & 0.038 & $-2.3 \%$ \\
Average 75 (four tests) & 0.051 & 0.046 & $10.5 \%$ \\
Average of Preliminary 50, Test 1, Test 2 and & 0.038 & 0.038 & $0.0 \%$ \\
Test 5 & 0.050 & 0.046 & $7.8 \%$ \\
Average of Preliminary 75, Test 3 and Test 4 & 0.031 & 0.038 & $-17.3 \%$ \\
Average of Test 6 and Test 7 & &
\end{tabular}

Table 5. Experimental mass loss rate values. Differences (\%) expressed in \% of the theoretical values 
(a) $50 \mathrm{~cm}$ pan tests

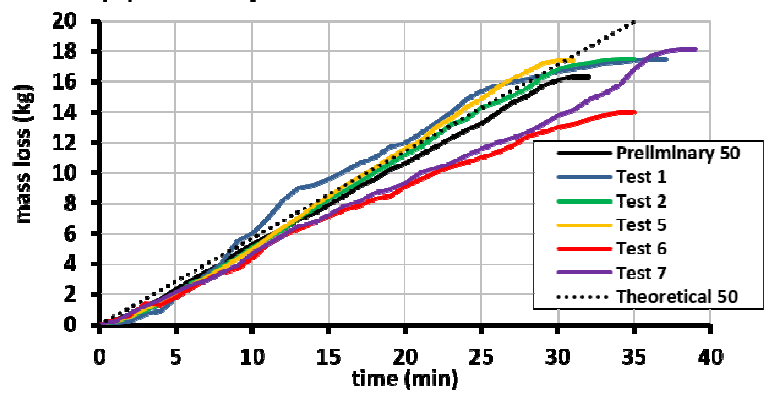

(b) $75 \mathrm{~cm}$ pan tests

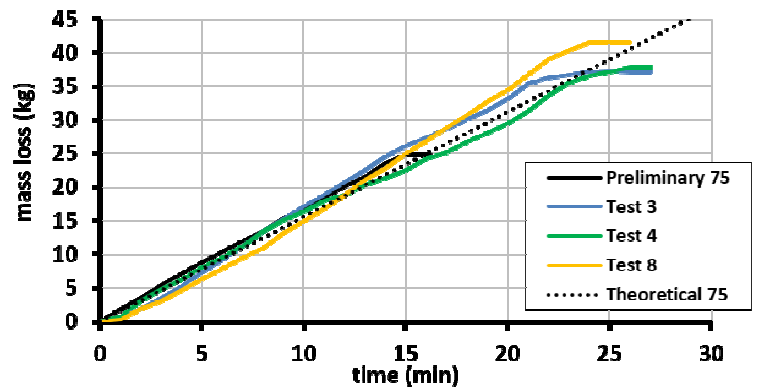

Figure 11. Mass loss evolution for (a) $50 \mathrm{~cm}$ side pan cases and (b) $75 \mathrm{~cm}$ side pan cases.

In view of the results, it can be concluded that:

- The experimental and theoretical mass loss rates are similar. The mean values are equal and $7.8 \%$ higher than theoretical for the 50 and $75 \mathrm{~cm}$ pans, respectively, if the singular cases (Tests 6, 7 and 8), which had a considerable effect on mass loss rate, are not taken into account.

- In spite of having reduced the wind effect (see Section 2.2.1), there were variations in mean mass loss rate of 11.8 and $13.0 \%$ in scenarios 1 and 2, respectively. In both cases, the tests with the strongest winds (1 and 3) showed the highest average value of mass loss per unit of area. In Fig. 12, the mass loss per unit of area per minute can be seen for the two tests in each of the scenarios 1 and 2. A curve is included to represent theoretical mass loss per surface unit in each case.

(a) Fire 1 (Test 1 and 2)

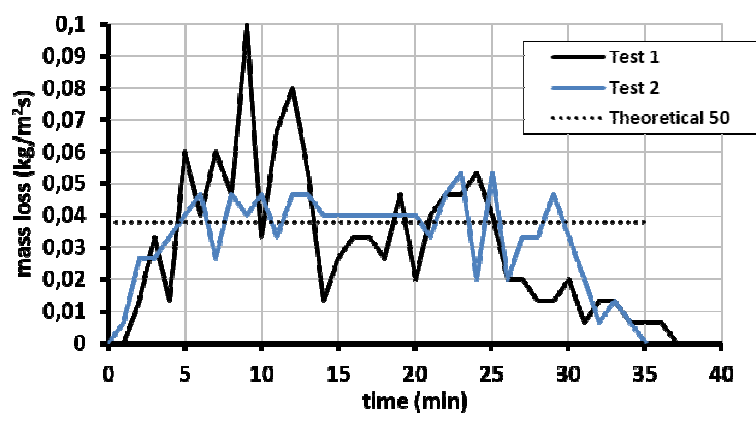

(b) Fire 2 (Test 3 and 4)

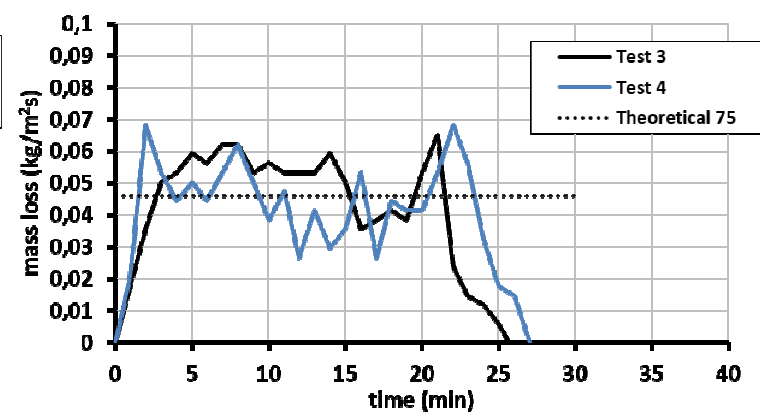

Figure 12. Mass loss rate evolution in time for (a) Fire 1 and (b) Fire 2.

- Tests 6 and 7, in which the pan is close to the abutment, show a mean mass loss rate $17 \%$ lower than the other cases with the $50 \mathrm{~cm}$ pan, due to the lack of adequate ventilation on the pan side close to the abutment. Tests 6 and 7 , at the same height as Test 5 , have a $25.8 \%$ lower mass loss rate, due to the abutment reducing the 
supply of oxygen by approximately $25 \%$ ( 1 of 4 sides) by acting as a physical barrier preventing the circulation of air.

- Test 8 had a mass loss rate $10.9 \%$ higher than that obtained in the three other tests with the $75 \mathrm{~cm}$ pan, due to the fire load being very close to the lower girder flanges $(1.1 \mathrm{~m})$, unlike Tests 3 and 4 , in which this distance was $60 \mathrm{~cm}$ greater $(1.7 \mathrm{~m})$. As the flames were closer, they spread further along the deck and increased the heat radiating surface over the pan itself.

\subsection{Temperatures}

\subsubsection{Vertical thermocouple tree}

Table 6 shows the maximum values recorded by the five TCs (V1 to V5) on the vertical TC tree, while Figure 13 gives the time evolution of these temperatures in Tests 7 and 8 . The temperature evolution in Tests 1 to 6 was not included, since these curves were quite similar to those of Test 7 .

\begin{tabular}{cccccc}
\hline $\begin{array}{c}\text { Test } \\
\text { name }\end{array}$ & V1 & V2 & V3 & V4 & V5 \\
\hline Test 1 & 786 & 597 & 431 & 282 & 280 \\
Test 2 & 765 & 535 & 455 & 315 & 308 \\
Test 3 & 796 & 873 & 813 & 745 & 758 \\
Test 4 & 863 & 886 & 840 & 743 & 702 \\
Test 5 & 813 & 711 & 568 & 596 & - \\
Test 6 & 848 & 774 & 704 & 604 & - \\
Test 7 & 847 & 649 & 675 & 527 & 589 \\
Test 8 & 908 & 885 & 901 & 908 & 926 \\
\hline
\end{tabular}

Table 6. Maximum temperatures recorded in the vertical thermocouple tree

The maximum temperatures in Tests 7 and 8 were in excess of 800 and $900^{\circ} \mathrm{C}$, respectively. In Test 7 the sensors temperature was seen to be in proportion to their distance from the fire, due to a vertical separation of $25-30 \mathrm{~cm}$ between the TCs. In Test 8 the readings of all the sensors are similar due to them being arranged in a length of $65 \mathrm{~cm}$ because of the short distance between the pan and the deck. 
(a) Test 7

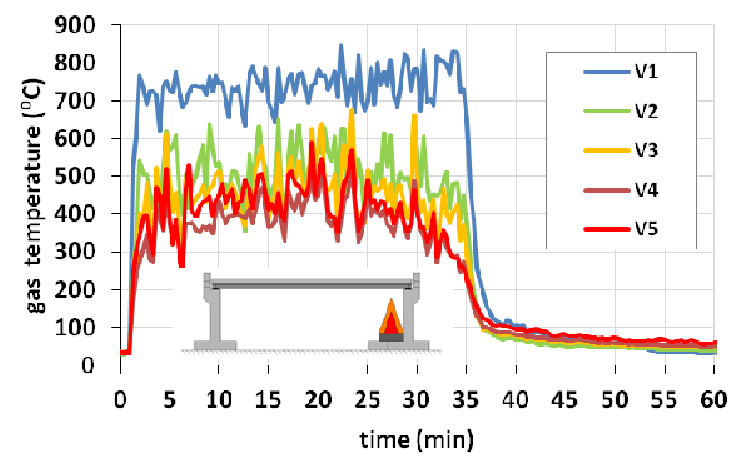

(b) Test 8

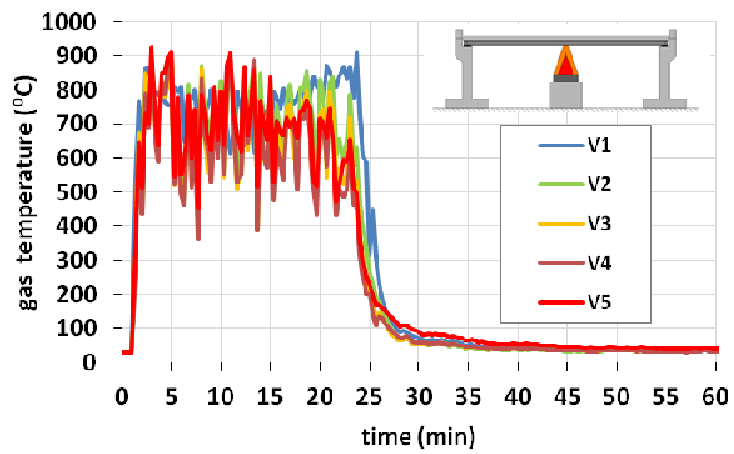

Figure 13. Temperatures recorded by vertical TCT: (a) Test 7 and (b) Test 8

\subsubsection{Gas temperatures}

Table 7 gives the maximum values reached by the six TCs (GC1 to GC6) in the central area between the two girders, while the evolution of these temperature in Tests 7 and 8 is shown in Figure 14.

\begin{tabular}{ccccccc}
\hline $\begin{array}{c}\text { Test } \\
\text { name }\end{array}$ & GC1 & GC2 & GC3 & GC4 & GC5 & GC6 \\
\hline Test 1 & 141 & 175 & 268 & 288 & 166 & 139 \\
Test 2 & 164 & 205 & 326 & 288 & 172 & 148 \\
Test 3 & 264 & 362 & 607 & 644 & 378 & 279 \\
Test 4 & 279 & 389 & 707 & 737 & 431 & 323 \\
Test 5 & 99 & 105 & 115 & 139 & 200 & 224 \\
Test 6 & 93 & 93 & 102 & 115 & 162 & 153 \\
Test 7 & 133 & 151 & 184 & 234 & 289 & 546 \\
Test 8 & 422 & 639 & 941 & 921 & 594 & 504 \\
\hline
\end{tabular}

Table 7. Maximum temperatures recorded in the gas between both girders.

In Figure 14 the temperatures recorded by TCs GC1 to GC6 can be seen to drop with the horizontal distance from the fire load. While in Test 7 (load close to the East abutment) the temperatures decrease from $500^{\circ} \mathrm{C}$ (GC6) to $280^{\circ} \mathrm{C}$ (GC5) in only $1 \mathrm{~m}$, in Test 8 they drop from $900^{\circ} \mathrm{C}$ (GC3) to $550^{\circ} \mathrm{C}(\mathrm{GC} 2)$ in the same distance. The thermal gradients for Tests 7 and 8 are therefore $220^{\circ} \mathrm{C} / \mathrm{m}$ and $350^{\circ} \mathrm{C} / \mathrm{m}$, respectively. 
(a) Test 7

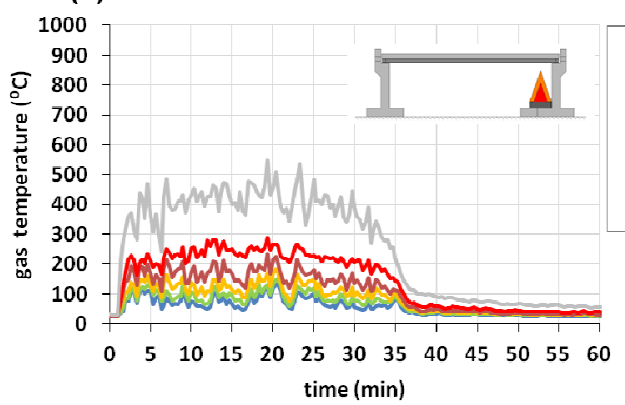

(b) Test 8

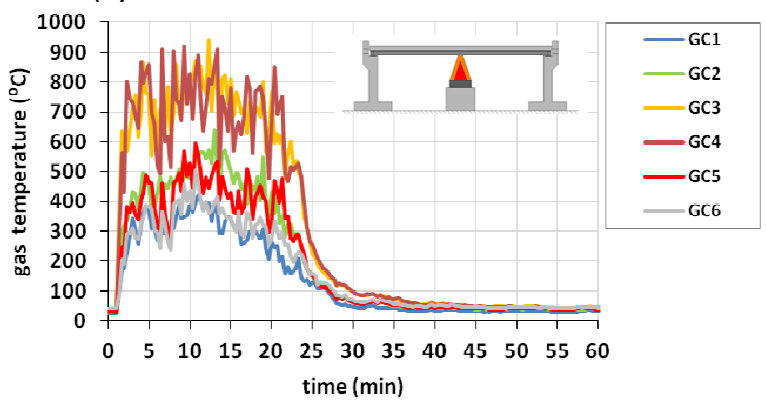

Figure 14. Temperatures recorded in the central region between the two bridge girders: (a) Test 7 and (b) Test 8.

Figure 15a gives the maximum gas temperatures registered in each of the regions studied (North, South, East and West) in the scenario Fire 2 (Tests 3 and 4). It can be seen that the central region over the fire load presents the highest temperature and that the wind has blown the flames towards the South. The maximum registered temperature differences between both tests in scenario Fire 2 reach $120^{\circ} \mathrm{C}$ at the sides and $60^{\circ} \mathrm{C}$ in the central zone, or around 30 and $10 \%$ of the maximum values registered at the sides and central zone, respectively.

(a) Fire 2 (Test 1 and 2)

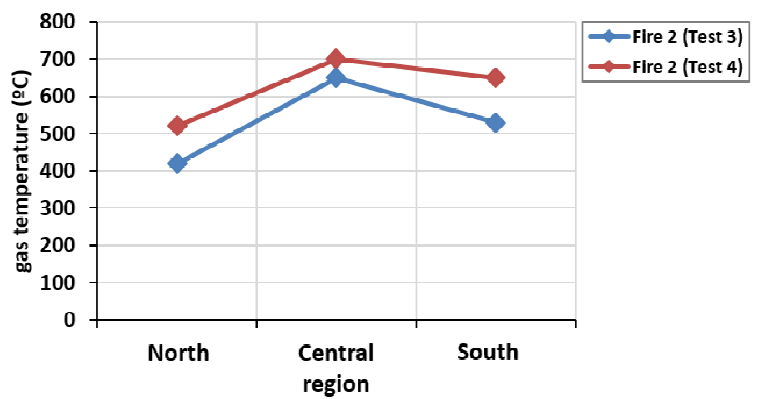

(b) Fire 1 to 4 (Test 2, 4, 7 and 8)

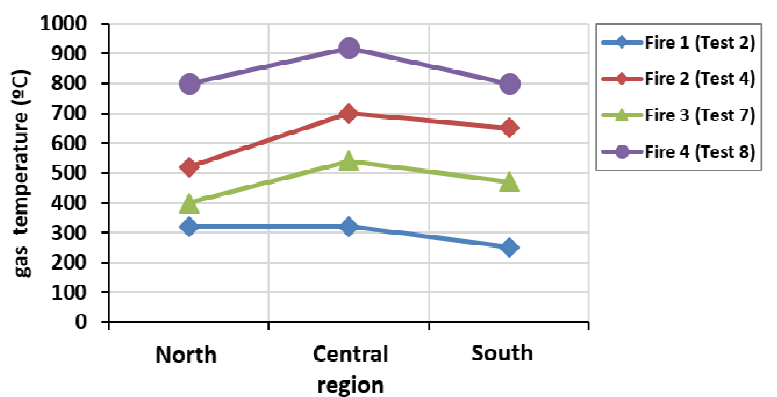

Figure 15. Maximum gas temperatures recorded per region: (a) Fire 2 and (b) four fire scenarios.

Fig. 15b compares the different fire scenarios in Tests 2, 4, 7 and 8, from which the following conclusions can be drawn:

- The maximum temperatures recorded by the horizontal TCTs were in the central region and reached $910^{\circ} \mathrm{C}$ in Test $8,700^{\circ} \mathrm{C}$ in Test $4,520^{\circ} \mathrm{C}$ in Test 7 and $310^{\circ} \mathrm{C}$ in Test 2. 
- The drop of $210^{\circ} \mathrm{C}$ in the central region between Tests 8 and 4 (both with the $75 \mathrm{~cm}$ pan) was due to the fire load in Test 8 being $1.1 \mathrm{~m}$ below the girder flanges, while in Test 4 this distance was $1.7 \mathrm{~m}$, or $60 \mathrm{~cm}$ greater.

- The drop of $210^{\circ} \mathrm{C}$ in the central region between Tests 7 and 2 (both with the $50 \mathrm{~cm}$ pan) can be attributed to the flames reaching higher in Test 7 for two reasons: a) the fuel pan was $0.3 \mathrm{~m}$ higher in Test 7 , and $\mathrm{b}$ ) in Test 7 , the pan containing the fuel was close to the East abutment, which reduced air entrainment by around $25 \%$ and meant that the gasoline required a greater height to combine with the available oxygen [35].

- The drop of $390^{\circ} \mathrm{C}$ in the central region between Tests 4 and 2 is due exclusively to the $63.4 \%$ lower heat release rate employed in Test 2 . This lower power not only reduced the height of the flames but also made the flames more susceptible to the effect of the wind.

- The similarity of the temperatures in the North and Central regions in Test 2 is due to the flames being permanently inclined over these zones.

- Fig. 16 gives the temperatures recorded by the gas sensors in the South, Central and North regions at 20 minutes after the start of the fire in Tests 7 and 8 . They show a considerable lateral temperature gradient in these three zones with maximum values of $212^{\circ} \mathrm{C} / \mathrm{m}$ in Test 7 and $377^{\circ} \mathrm{C} / \mathrm{m}$ in Test 8 .

\section{(a) Test 7 (20 min)}

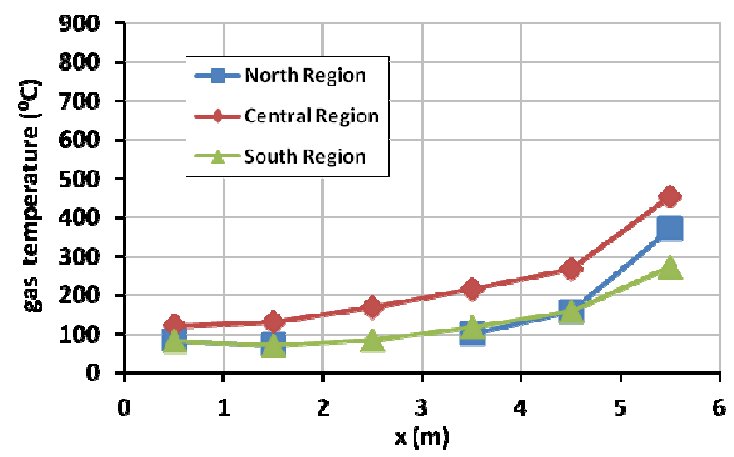

(b) Test 8 (20 min)

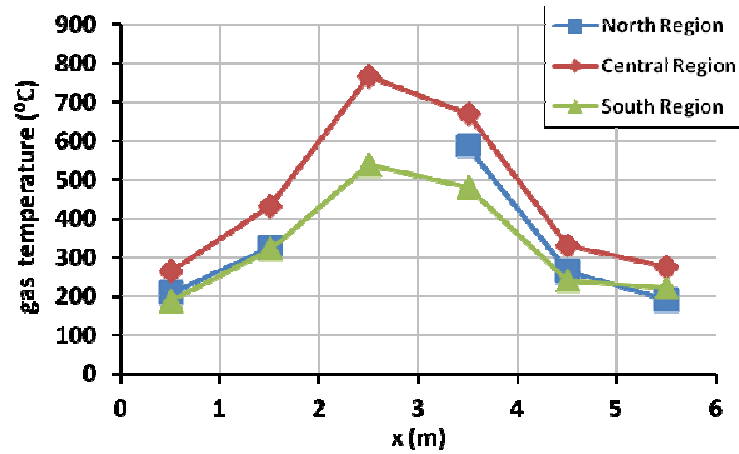

Figure 16. Gas temperatures recorded 20 minutes after the beginning of (a) Test 7 and (b) Test 8 
Alos-Moya J., Paya-Zaforteza I., Hospitaler A., Rinaudo P.

Valencia bridge fire tests: Experimental study of a composite bridge under fire (2017) Journal of Constructional Steel Research, 138, pp. 538-554. DOI: 10.1016/j.jcsr.2017.08.008

\subsubsection{Steel temperatures}

Table 8 gives the maximum temperatures recorded in each of the eight tests by the 28 TCs placed on the steel girders. The results are grouped by girders, with the bottom flange sensors first, followed by web and top flange sensors.

\begin{tabular}{|c|c|c|c|c|c|c|c|c|}
\hline North Girder & Test 1 & Test 2 & Test 3 & Test 4 & Test 5 & Test 6 & Test 7 & Test 8 \\
\hline NG-BF1 & 74 & 89 & 131 & 187 & 51 & 46 & 64 & 269 \\
\hline NG-BF2 & 113 & 138 & 206 & 288 & 49 & 48 & 75 & 459 \\
\hline NG-BF3 & 170 & 226 & 294 & 467 & 63 & 60 & 98 & 707 \\
\hline NG-BF4 & 163 & 215 & 279 & 442 & 97 & 88 & 144 & 727 \\
\hline NG-BF5 & 111 & 130 & 212 & 257 & 211 & 160 & 258 & 447 \\
\hline NG-BF6 & 79 & 93 & 135 & 170 & 386 & 283 & 469 & 303 \\
\hline NG-W1 & 83 & 92 & 151 & 190 & 57 & 52 & 78 & 278 \\
\hline NG-W2 & 124 & 147 & 236 & 291 & 61 & 56 & 93 & 479 \\
\hline NG-W3 & 165 & 215 & 337 & 451 & 71 & 66 & 110 & 713 \\
\hline NG-W4 & 175 & 210 & 337 & 454 & 109 & 100 & 167 & 749 \\
\hline NG-W5 & 116 & 128 & 217 & 274 & 157 & 126 & 269 & 466 \\
\hline NG-W6 & 85 & 96 & 149 & 185 & 270 & 201 & 465 & 304 \\
\hline NG-TF3 & 138 & 173 & 278 & 356 & 70 & 64 & 98 & 568 \\
\hline NG-TF4 & 147 & 175 & 286 & 371 & 103 & 94 & 147 & 626 \\
\hline South Girder & Test 1 & Test 2 & Test 3 & Test 4 & Test 5 & Test 6 & Test 7 & Test 8 \\
\hline SG-BF 1 & 89 & 101 & 165 & 207 & 58 & 51 & 75 & 287 \\
\hline SG-BF2 & 140 & 141 & 295 & 330 & 52 & 52 & 81 & 465 \\
\hline SG-BF3 & 232 & 214 & 459 & 512 & 62 & 64 & 99 & 725 \\
\hline SG-BF4 & 220 & 203 & 428 & 490 & 97 & 98 & 153 & 733 \\
\hline SG-BF5 & 130 & 132 & 245 & 292 & 200 & 192 & 271 & 475 \\
\hline SG-BF6 & 78 & 89 & 127 & 169 & 365 & 364 & 458 & 297 \\
\hline SG-W1 & 89 & 103 & 179 & 203 & 61 & 53 & 79 & 291 \\
\hline SG-W2 & 134 & 146 & 289 & 325 & 63 & 57 & 90 & 465 \\
\hline SG-W3 & 203 & 211 & 449 & 507 & 81 & 73 & 119 & 747 \\
\hline SG-W4 & 193 & 193 & 398 & 476 & 103 & 97 & 155 & 735 \\
\hline SG-W5 & 127 & 131 & 289 & 310 & 153 & 152 & 262 & 488 \\
\hline SG-W6 & 97 & 107 & 219 & 228 & 247 & 244 & 462 & 353 \\
\hline SG-TF3 & 133 & 149 & 295 & 380 & 54 & 53 & 77 & 543 \\
\hline SG-TF4 & 139 & 148 & 287 & 367 & 84 & 81 & 120 & 569 \\
\hline
\end{tabular}

Table 8. Maximum steel temperatures in ${ }^{\circ} \mathrm{C}$ recorded in the North and South Girder.

Table 8 shows that:

- Maximum steel temperatures in Tests $1,2,5$ and 6 were below $400^{\circ} \mathrm{C}$, the critical temperature that marks the beginning of the reduction of the steel yield strength, according to EC-3 part 1-2 [40]. 
- Maximum steel temperatures in Tests 3 and 4 were 459 and $512{ }^{\circ} \mathrm{C}$ respectively and were reached at the bottom flange of the South Girder (section S3 near mid-span in Fig. 6). The maximum temperature in Test 7 was $469^{\circ} \mathrm{C}$ at the bottom flange of the North Girder (Section S6 close to the East abutment).

Fig. 17 gives the temperatures in the hottest sections in Test 7 (Section S6) and Test 8 (Section S4). The following comments can be made:

- In both tests the bottom flange temperatures and web temperatures were quite similar. These temperatures were around $430^{\circ} \mathrm{C}$ in Test 7 and $700^{\circ} \mathrm{C}$ in Test 8.

- In Test 8 (see Fig.17b) maximum top flange temperatures were around 550 and $600^{\circ} \mathrm{C}$ and were between 100 and $150^{\circ} \mathrm{C}$ below the maximum temperatures recorded in the webs and bottom flanges. This temperature difference was due to (a) the bottom flange and the web having more steel surface exposed to the fire than the top flange; and (b) the top face of the top flange being protected by the RC slab. This difference in temperatures was also observed in previous studies in which steel and composite I-girders used in bridges were uniformly heated (see e.g. Paya-Zaforteza and Garlock [12]) or submitted to realistic fire scenarios (see e.g. Alos-Moya et al. [23], Peris-Sayol et al. [24, 25],) or submitted to a standard fire in a furnace (Aziz et al. [28]).

- Maximum steel temperatures in Test 8 varied between $569^{\circ} \mathrm{C}$ and $749^{\circ} \mathrm{C}$. These values are in the order of magnitude of those observed in real bridge fire events. The numerical model of the fire under the I-65 overpass in Birmingham, Alabama (USA) carried out by Alos-Moya et al. [23], estimated that the steel girders of the overpass reached peak temperatures between approximately $500^{\circ} \mathrm{C}$ and $800^{\circ} \mathrm{C}$. Similarly, Godart et al. [37] reported that significant areas of the Mathilde Bridge in Rouen (France) reached at least $600^{\circ} \mathrm{C}$ as a consequence of the fire under the bridge in 2012. 
(a) Test 7 (Section 6)

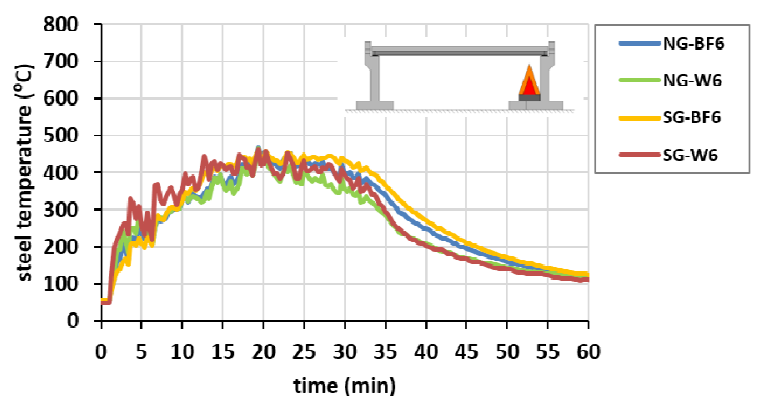

(b) Test 8 (Section 4)

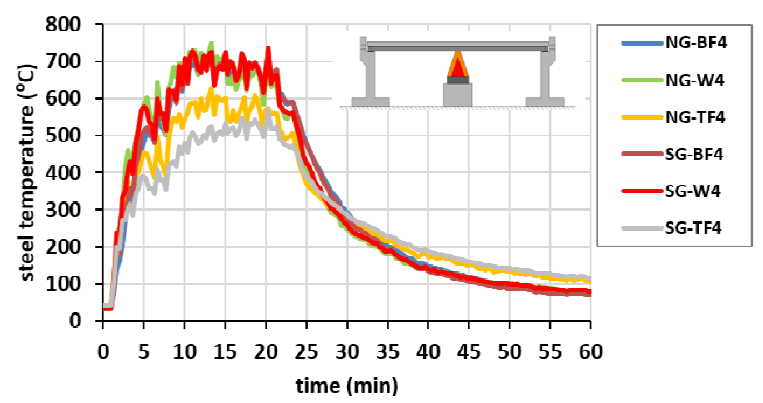

Figure 17. Steel temperatures in the hottest section: (a) Test 7 (Section S6) and (b) Test 8 (Section S4).

Figure 18 gives the temperature evolution of the TCs on the lower flange of the South Girder in Tests 7 and 8 . The maximum gradients in the steel of the lower flange of the South Girder are $200^{\circ} \mathrm{C} / \mathrm{m}$ and $250^{\circ} \mathrm{C} / \mathrm{m}$ for Tests 7 and 8 , respectively, and are slightly lower than those recorded in the gas. The graphs of the sensors in the web and the North Girder are not shown for being similar to those given here.

(a) Test 7

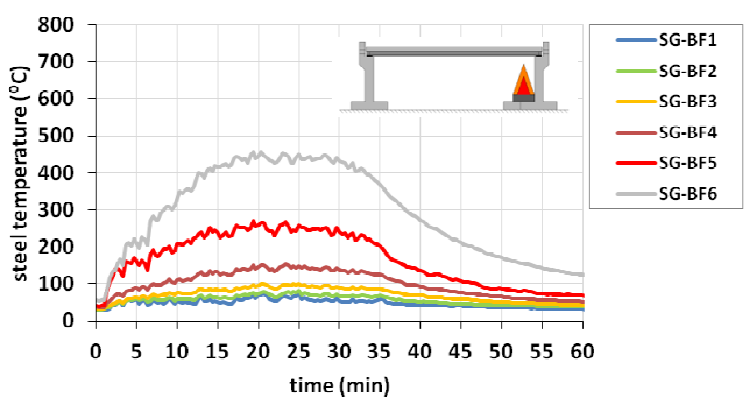

(b) Test 8

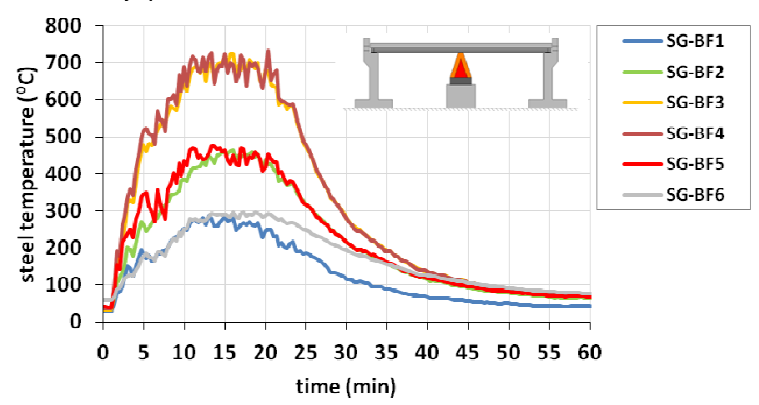

Figure 18. Steel temperatures on the bottom flange of the South Girder for (a) Test 7 and (b) Test 8.

Figure 19 compares the maximum temperatures in different zones of the steel girders and different sections of the fire scenarios considered. Based on Figure 19a, it can be stated that:

- There are no significant differences between the temperatures recorded in the web and bottom flange in any of the four scenarios studied.

- There are considerable differences between the web and top flange temperatures as a result of the proximity of the slab: around $150^{\circ} \mathrm{C}$ for the scenario Fire $4,120^{\circ} \mathrm{C}$ for scenario Fire 2 and $40^{\circ} \mathrm{C}$ for scenario Fire 1. 
- In scenario Fire 4 the North girder temperatures are slightly lower (in lower flange, web and upper flange) as a result of the flames being blown towards the South.

- As no information is available on the temperature of the top flange in Section 6 in scenario Fire 3, no assessment can be made of the gradient between the web and top flange.

Fig. 19b gives the maximum temperatures in each section (including both girders) for the four fire scenarios. Maximum gradients for scenarios Fire 1, Fire 2, Fire 3 and Fire 4 are 60, 200,200 and $250^{\circ} \mathrm{C} / \mathrm{m}$, respectively. In addition, taking Fire 2 as reference with a recorded maximum temperature of $500^{\circ} \mathrm{C}$, it can be seen that:

- There is a rise of $250^{\circ} \mathrm{C}$ over this temperature when the fire load position is raised from 0.2 to $0.8 \mathrm{~m}$ over the reference level.

- There is a drop of $290^{\circ} \mathrm{C}$ below this temperature when the power is reduced by $63.4 \%$ of the $1135 \mathrm{~kW}$ of scenario Fire 2.

Finally, the representation of the scenario Fire 3 in Figure $19 \mathrm{~b}$ also shows that the longitudinal thermal gradient is reduced with horizontal distance from the fire.

(a) Fire 1 to 4 (by region)

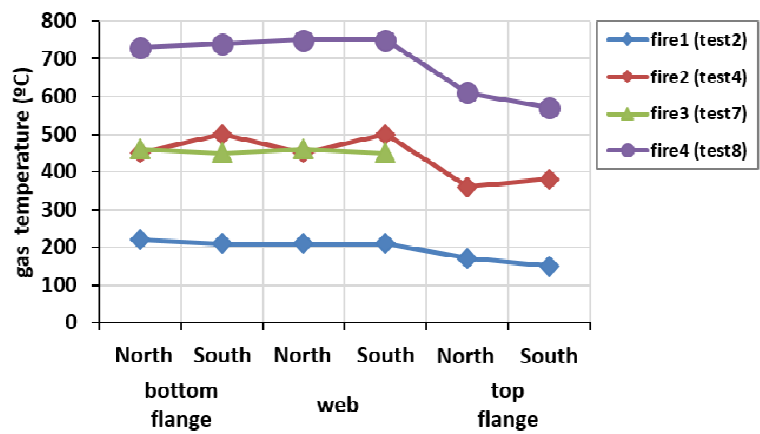

(b) Fire 1 to 4 (by section)

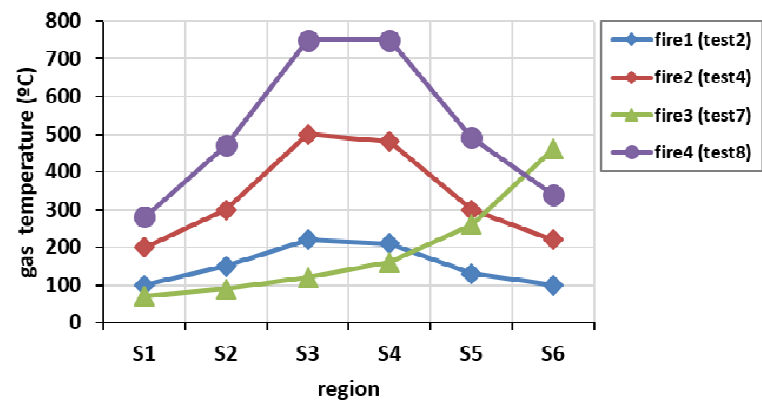

Figure 19. Maximum steel temperatures in four representative tests: (a) by region and (b) by section.

\subsubsection{Reinforced concrete slab temperatures}

The temperatures recorded in the reinforcing bars and shear studs of the RC slab were found to be between 69 and $190^{\circ} \mathrm{C}$ and 48 and $110^{\circ} \mathrm{C}$, respectively. The maximum values were reached in Test 8 . No concrete spalling was observed, which can be attributed to the low value of the concrete temperatures and the low moisture content of the slab. 


\subsection{Deflections}

Measuring vertical deflections during a fire test is important to evaluate the damage caused by the fire to the structure and to obtain a set of data to calibrate the structural models of the fire tests.

Vertical deflections in the Valencia bridge fire tests were obtained by trigonometry from the displacement increments recorded by each pair of LVDTs. Table 9 gives the maximum deflections recorded by the LVDTs in the deck sections with coordinates $x=1,3$ and $5 \mathrm{~m}$. It can be concluded that:

- Even though Tests 3 and 4 belonged to the same fire scenario, in Test 3 the midspan maximum deflections were $29 \%$ lower due to the higher wind speed during this test.

- Maximum deflections in Test 2 (Fire 1) were 67\% lower than Test 4 (Fire 2) as the fire load was reduced by $63.4 \%$ and the pan level was kept the same ( $z$ coordinate equal to $0.20 \mathrm{~m}$ ).

- Both Test 8 (Fire 4) and Test 4 (Fire 2) involved a 1131 kW fire load. However, maximum deflections recorded in Test 8 increased by about $67 \%$ over Test 4 because the vertical distance between the fire load and girders was reduced by 0.6 $\mathrm{m}$.

\begin{tabular}{ccccccc}
\hline \multirow{2}{*}{$\begin{array}{c}\text { Test } \\
\text { Name }\end{array}$} & \multicolumn{2}{c}{$\mathbf{x}=1.0 \mathrm{~m}$} & \multicolumn{2}{c}{$\begin{array}{c}\text { Vertical Deflections }(\mathrm{mm}) \\
\mathrm{x}=3.0 \mathrm{~m}\end{array}$} & \multicolumn{2}{c}{$\mathrm{x}=5.0 \mathrm{~m}$} \\
& North & South & North & South & North & South \\
\hline Test 1 & 11 & 12 & 24 & 25 & 11 & 11 \\
Test 2 & 11 & 11 & 24 & 24 & 11 & 10 \\
Test 3 & 25 & 30 & 51 & 55 & 24 & 24 \\
Test 4 & 34 & 38 & 71 & 73 & 33 & 32 \\
Test 5 & 5 & 5 & 15 & 15 & 15 & 13 \\
Test 6 & 4 & 4 & 12 & 12 & 11 & 11 \\
Test 7 & 7 & 7 & 19 & 19 & 17 & 16 \\
Test 8 & 57 & 57 & 121 & 120 & 59 & 56 \\
\hline
\end{tabular}

Table 9. Maximum vertical deflections $(\mathrm{mm})$ for all the tests.

The following comments should be noted in regard to the horizontal displacements: 
- The maximum values were obtained in Test 8 (Fire 4 scenario) and were $14 \mathrm{~mm}$ on the East side and $11 \mathrm{~mm}$ on the West.

- In the remaining tests horizontal displacements were in no case greater than $5 \mathrm{~mm}$.

- Horizontal displacements were similar in all the tests.

- No horizontal displacements were recorded by the LVDTs on the steel frames (L21 and L22), which indicates that the auxiliary frames did not experience any strain that could have an influence on the measurements taken by L1 to L20.

The evolution of the maximum mid-span deflections in Tests 2, 4, 7 and 8 can be seen in Fig. 20. The following comments can be made:

- Maximum vertical deflections of $121,71,24$ and $19 \mathrm{~mm}$ were reached in fire scenarios 4, 2, 1 and 3, respectively. Fig. 21 shows two views taken during Test 8 (Fire 4 ) in the period of the greatest slab deformation.

- Similar vertical deflections were recorded in both girders, as also occurred in the sections at $x=1 \mathrm{~m}$ and $\mathrm{x}=5 \mathrm{~m}$, as can be seen in Table 7 .

- The fact that maximum vertical deflections in the Fire 4 scenario were experienced for six minutes indicates that the composite deck reached an equilibrium state. During this period, the distance between the fire load and the steel girders was only $0.98 \mathrm{~m}$ due to the deck deflection of $0.12 \mathrm{~m}$.

- No residual deflections were recorded after the tests had been carried out, which leads to the conclusion that the bridge deformations were caused by the reduction of the Young's modulus of the steel girders and by the thermal expansion of the girders. The lack of residual deformations after the tests also indicates that the girders did not suffer any plastic damage. 
(a) North Girder

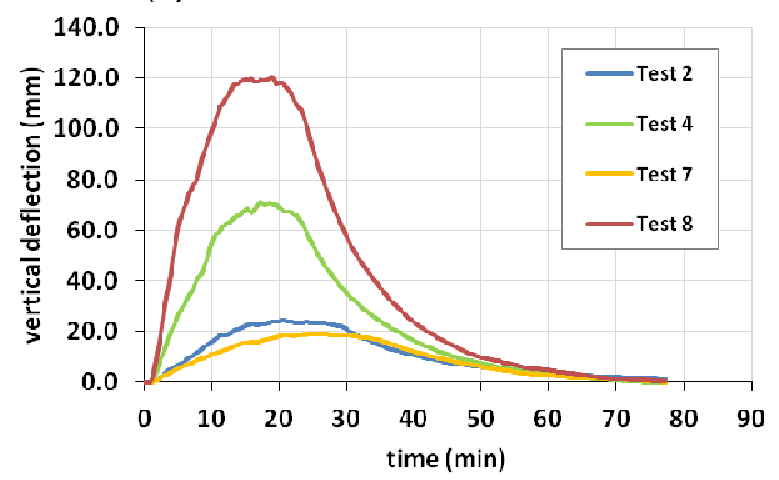

(b) South Girder

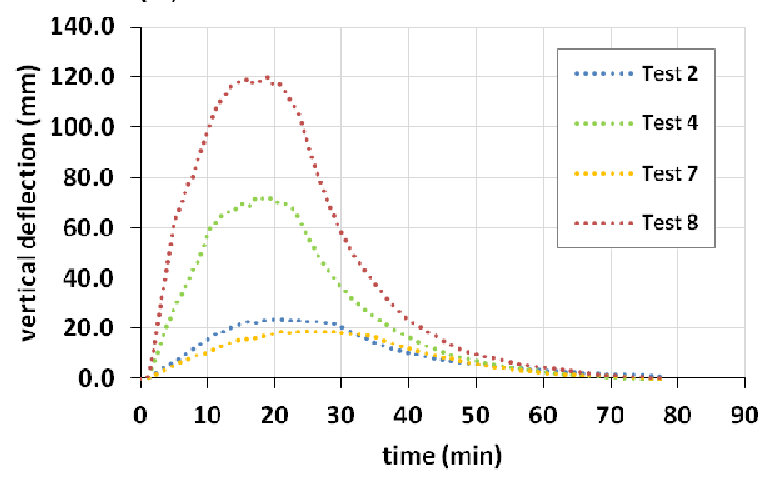

Figure 20. Vertical deflection at mid-span for (a) North Girder and (b) South Girder
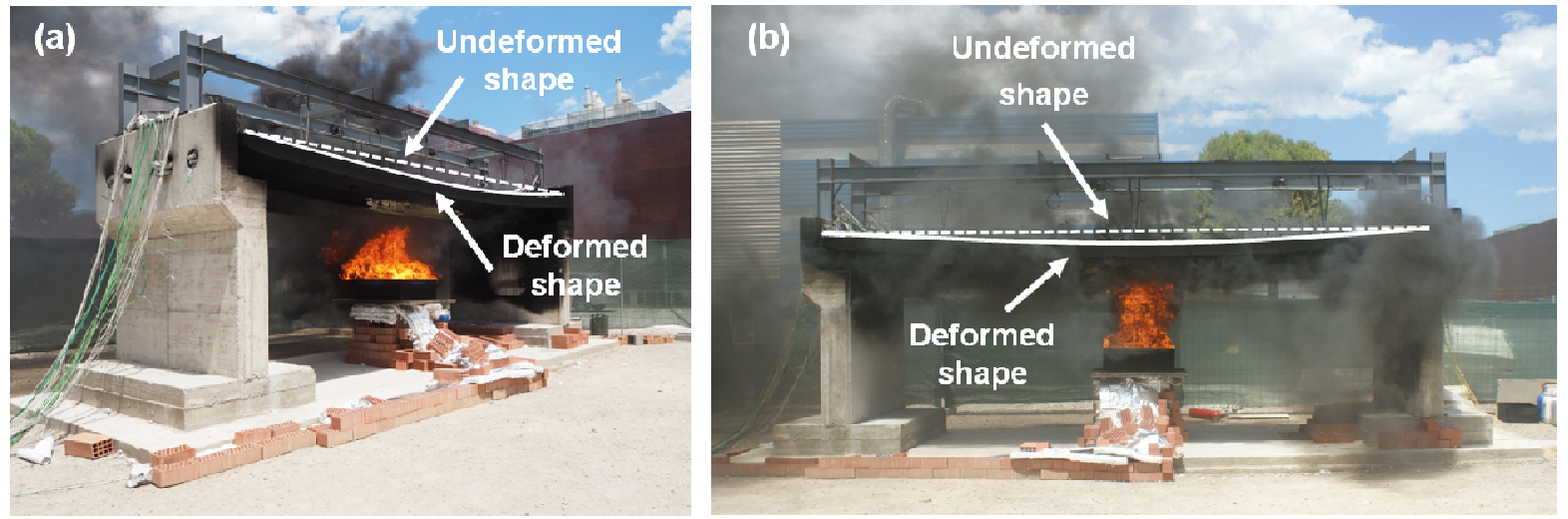

Figure 21. Test 8: (a) perspective view and (b) front view of bridge showing the maximum vertical deflection reached.

\section{Conclusions and future work.}

The serious consequences of bridge fires and the failure of current codes to give guidance on estimating a bridge fire resistance give rise to the need to develop a performance-based approach to bridge fire protection. This approach could be based on the results of numerical models, but would also require experiments to (1) enable the calibration of the numerical models and (2) provide useful quantitative and qualitative information on bridge fires.

Despite its importance, experimental work on bridge fires is quite scarce and the few existing studies do not reproduce some important bridge fire characteristics, such as the heating curves of hydrocarbon fires and the existence of longitudinal thermal gradients. In addition, previous experimental works do not analyze the influence of the expansion joints on the bridge response, the position of the fire load, or the vertical clearance.

Within this context, this paper describes two sets of fire tests conducted at the Universitat Politècnica de València in Valencia, Spain to improve current knowledge on the response of 
bridges to fires. The first set (called "preliminary tests") did not involve any bridge and was aimed at providing the authors with important information on how to perform open air fire tests efficiently and safely. The second set of fire tests involved a series of eight fires of different magnitudes and at different positions under a $6 \mathrm{~m}$ long l-girder composite bridge. This second set reproduced fire scenarios similar to those of real bridge fires, although smaller in magnitude. This decision to use smaller fire loads made it possible to use the experimental bridge in several tests and was also due to economic, safety and environmental reasons.

From both series of tests, the following conclusions can be drawn:

- The experimental values of the mass loss rate are, in general, similar to the values proposed in the literature. Significant differences between the experimental and theoretical values were observed in Tests 6 and $7(-17.3 \%$ of average value) and Test $8(+18.7 \%)$ due to reduced air entrainment (Tests 6 and 7$)$ and the increase of deck surface that radiated heat over the pan containing the fuel (Test 8).

- Maximum gas temperatures are reached in the central region between the two girders and vary between $320^{\circ} \mathrm{C}$ (Fire 1 scenario) and $920^{\circ} \mathrm{C}$ (Fire 4 scenario).

- Gas temperatures vary widely along the longitudinal axis of the bridge. For example, the average longitudinal thermal gradient is $350^{\circ} \mathrm{C} / \mathrm{m}$ for the Fire 4 scenario and $220^{\circ} \mathrm{C} / \mathrm{m}$ for Fire 3 . The temperatures in the steel girders also prove the existence of an important longitudinal thermal gradient $\left(250^{\circ} \mathrm{C} / \mathrm{m}\right.$ for Fire 4 scenario, $200^{\circ} \mathrm{C} / \mathrm{m}$ in Fire scenarios 2 and 3 , and $60^{\circ} \mathrm{C} / \mathrm{m}$ in the Fire 1 scenario. This means assuming a uniform gas or girder temperature along the longitudinal axis of the bridge is unrealistic, even for small span bridges, and should be avoided.

- Maximum web and bottom flange girder temperatures are very similar and range between $220^{\circ} \mathrm{C}$ (Test 2, Fire 1) and $720^{\circ} \mathrm{C}$ (Test 8, Fire 4). Top flange temperatures are significantly smaller because the top flange is partially protected by the top RC slab.

- The power of the fire and the vertical distance from the fire to the bridge deck have a strong influence on the response of the bridge. For example: (a) keeping the firedeck distance constant $(1.7 \mathrm{~m})$ but reducing the power of the fire load from $1131 \mathrm{~kW}$ (Fire 2) to $415 \mathrm{~kW}$ (Fire 1) reduced the maximum vertical deflection of the deck by $67 \%$; (b) keeping the power constant (1131 kW) but reducing the vertical distance 
between the fire and the bottom flange from 1.7 (Fire 2) to $1.1 \mathrm{~m}$ (Fire 4) resulted in a $66 \%$ increase in the maximum deflections. The existence of this influence had already been foreseen in the analysis of a typical steel I-girder bridge carried out by Peris-Sayol et al. [18], but the experiments described here have verified it experimentally for the first time.

- The maximum deflection registered in both girders was $120 \mathrm{~mm}$ in Fire 4, which had a power of $1131 \mathrm{~kW}$ and a distance between fire load and girders of $1.1 \mathrm{~m}$. The bridge recovered its initial geometry after the test and no plastic deformation in the steel girders or spalling in the concrete slab was observed.

- Wind can have a very strong influence on open air fire tests. For example, Tests 3 and 4 were in the same fire scenario. However, the maximum mid-span vertical deflection in Test 3 was $29 \%$ smaller than in Test 4 . This effect was due to the higher wind speed in Test 3 , which deflected the flames. Wind speed should therefore be under a predefined threshold before conducting any open air fire test.

The results provided in this paper are of major importance for researchers and practitioners interested in protecting bridges from fires and in increasing bridge resilience since:

a) They provide a quantitative and qualitative idea of what happens to a bridge when a fire breaks out under its deck.

b) The data measured in relation to mass loss rate and gas temperatures can be used to validate the numerical models that analyze the fire event.

c) The data measured in relation to deck temperatures and deflections enables the validation of the thermo-structural models that give the response of the bridge through time.

d) These validated numerical models could then be used to predict: (a) the damage caused by fires to bridges and the bridges residual strength, (b) the damage reduction associated with different potential protection measures.

e) Furthermore, the information provided in this paper will be useful to anyone interested in carrying out open air experimental tests to study bridge fires.

Future work in this area should involve higher fire loads capable of causing substantial damage to a bridge in order to better study bridge residual strength and failure mechanisms. It would also be of great interest to carry out experimental tests with other deck structural 
systems and construction materials (e.g. prestressed concrete or box-girders) as well as other bridge configurations (for example, fires under multi-span bridges).

\section{Acknowledgements.}

Funding for this research was provided by the Spanish Ministry of Science and Innovation (Research Project BIA 2011-27104). The authors are grateful to the Infrastructure and Safety departments of the Universitat Politècnica de València and the City of Valencia Fire Department (Cuerpo de Bomberos de Valencia), which provided crucial support in conducting the tests. Finally, the authors would like to thank Dr. Luke Bisby from the University of Edinburgh, and Dr. Juan Hidalgo and Dr. Cristian Maluk from the University of Queensland for their advice and support during the early stages of planning the fire tests.

\section{References}

[1] Ghosn M, Moses F, Wang J. NCHRP Report 489. Design of Highway Bridges for Extreme Events. Transportation Research Board of the National Academies. Washington D.C., USA. 2003.

[2] Peris-Sayol G, Paya-Zaforteza I, Balasch-Parisi S, Alos-Moya J. Detailed Analysis of the Causes of Bridge Fires and Their Associated Damage Levels. Journal of Performance of Constructed Facilities 2017; 31(3). doi: 10.1061/(ASCE)CF.1943-5509.

[3] Wright W., Lattimer B., Woodworth M., Nahid M., and Sotelino E. Highway bridge fire assessment draft final report. NCHRP Program Transportation Research Board of the National Academies. Virginia Polytechnic Institute and State University. Blacksburg, VA; 2013.

[4] Garlock ME, Paya-Zaforteza I, Gu L, Kodur V. Fire hazard in bridges: review, assesment and repair strategies. Engineering Structures 2012;35:89-98.

[5] San Francisco Gate. The Maze Meltdown. www.sfgate.com. Accessed Dec. 12, 2016.

[6] Chung P, Wolfe RW, Ostrom T, Hida S, editors. Accelerated bridge construction applications in California - a lessons learned. Report issued by the California Department of, Transportation; 2008.

[7] Le Figaro. "Pont de Rouen: le routier ne paiera pas les dégâts." "Rouen Bridge: the truck driver will not pay the damage." http://www.lefigaro.fr. Accessed Oct. 24, 2015. In French.

[8] Fischer EC, Varma AH. Fire resilience of composite beams with simple connections: Parametric studies and design. Journal of Constructional Steel Research 2017; 128: 119135. doi: 10.1016/j.jcsr.2016.08.004

[9] Gernay T, Elhami Khorasani N, Garlock M. Fire fragility curves for steel buildings in a community context: A methodology. Engineering Structures. 2016;113:259-276. http://dx.doi.org/10.1016/j.engstruct.2016.01.043 
[10] Rodrigues JPC, Laím, L. Fire resistance of restrained composite columns made of concrete filled hollow sections. Journal of Constructional Steel Research 2017;133:65-76. doi: 10.1016/j.jcsr.2017.02.011

[11] Rinaudo P, Paya-Zaforteza I, Calderón PA. Improving tunnel resilience against fires: A new methodology based on temperature monitoring. Tunnelling and Underground Space Technology 2016;52:71-84. DOI: 10.1016/j.tust.2015.11.021

[12] Payá-Zaforteza I, Garlock M. A numerical investigation on the fire response of a steel girder bridge. Journal of Construction Steel Research 2012;75:93-103.

[13] Peris-Sayol G, Paya-Zaforteza I, Balasch-Parisi S, Alos-Moya J. Analysis of the Factors that Influence the Maximum Adiabatic Temperatures in I-girder Bridges. 9th International Conference on Structures in Fire (SiF), Princeton, NJ, 2016, pages 743-750

[14] Glassman, JD, Moreyra Garlock ME. Compression model for ultimate postbuckling shear strength at elevated temperatures. Journal of Structural Engineering, 2017, 143(6): 04017023

[15] Buchanan A.H., Abu A.K. Structural design for fire safety. John Wiley \& Sons; 2017.

[16] CEN (European Committee for Standardization). Actions on structures, part 1-2: general actions - actions on structures exposed to fire. Brussels (Belgium), 2002.

[17] Ingason H., Li Y.Z., Lönnermark A. Tunnel fire dynamics. Springer; 2015. DOI 10.1007/978-1-4939-2199-7

[18] ITA (International Tunneling and Underground Space Association). Structural fire protection for road tunnels. ITA Report 18, 2017.

[19] NFPA (National Fire Protection Association). NFPA 502: Standard for road tunnels, bridges, and other limited highways. Quincy, MA, USA, 2017.

[20] Naser, MZ., Kodur VKR. A probabilistic assessment for classification of bridges against fire hazard. Fire Safety Journal 2015;76: 65-73.

[21] Gil H, Seo S, Park C. Fire Risk Management for Highway Bridges in Korea. IABSE Conference Geneva (Switzerland). Structural Engineering: Providing Solutions to Global Challenges. Report p. 890-896.

[22] Quiel S.E, Yokoyama T, Bregman L.S, Mueller K.A, Marjanishvili S.M. A streamlined framework for calculating the response of steel-supported bridges to open-air tanker truck fires. Fire Safety Journal 2015;73:63-65.

[23] Alos-Moya J, Paya-Zaforteza I, Garlock MEM, Loma-Ossorio E, Schiffner D, Hospitaler A. Analysis of a bridge failure due to fire using computational fluid dynamics and finite element models. Engineering Structures 2014;68:96-110.

[24] Peris-Sayol G, Alós-Moya J, Payá-Zaforteza I, Hospitaler-Pérez A. A parametric study on the thermo-mechanical response of a multi-girder steel bridge submitted to real fires (Estudio paramétrico de la respuesta termo-estructural de un puente metálico multijácena sometido a incendios reales). Informes de la Construcción 2014;66 (No Extra-1):1-11 http://dx.doi.org/10.3989/ic.13.077 . In Spanish. 
[25] Peris-Sayol G, Paya-Zaforteza I, Alos-Moya J, Hospitaler A. Analysis of the influence of geometric, modeling and environmental parameters on the fire response of steel bridges subjected to realistic fire scenarios. Computers and Structures 2015;158:333-345.

[26] Gong X, Agrawal AK. Numerical Simulation of Fire Damage to a Long-Span Truss Bridge. Journal Bridge Engineering 2015;20(10). doi: 10.1061/(ASCE)BE.19435592.0000707\#sthash.nhj5KqVo.dpuf

[27] Gong X, Agrawal AK. Safety of Cable-Supported Bridges during Fire Hazards. Journal of Bridge Engineering 21(4). doi: 10.1061/(ASCE)BE.1943-5592.0000870

[28] Aziz, EM, Kodur VK, Glassman, JD, Moreyra Garlock ME. Behavior of steel bridge girders under fire conditions. Journal of Constructional Steel Research 2016; 106:1122. doi: 10.1016/j.jcsr.2014.12.001.

[29] Taly N. Design of modern highway bridges. McGrawHill, 1998.

[30] Llago Acero R., García Rodríguez P. Composite twin-girder bridges: a competitive solution for medium span bridges. Revista de Obras Públicas 2010:1695;29-46. In Spanish.

[31] Taranath BS. Steel, concrete and composite design of tall buildings. McGrawHill, USA, 1997.

[32] Nadjai A, Han S, Ali F, Alam N, Allam A. Fire resistance of axial restraint composite floor steel cellular beams. Journal of Constructional Steel Research 2017:136;229-37. DOI: 10.1016/j.jcsr.2017.05.016.

[33] Li GQ, Zhang N, Jiang J. Experimental investigation on thermal and mechanical behaviour of composite floors exposed to standard fire. Fire Safety Journal 2017;89:63-76. DOI:10.1016/j.firesaf.2017.02.009.

[34] Bailey CG, Toh WS. Behaviour of concrete floor slabs at ambient and elevated temperatures. Fire Safety Journal 2007;42 (6-7):425-36. DOI:10.1016/j.firesaf.2006.11.009.

[35] Drysdale D. An Introduction to Fire Dynamics. John Wiley and Sons. United Kingdom; 2011.

[36] Babrauskas V. Chapter 26. Heat Release rates. In: SFPE handbook of fire protection engineering, 5th ed. 2016. p. 799-904.

[37] Godart B, Berthellemy J, Lucas JP. Diagnosis, assessment and repair of the Mathilde bridge close to collapse during a fire. Structural Engineering International 2015;25(3):331-38

[38] Rinaudo P, Paya-Zaforteza I, Calderón P, Sales S. Experimental and analytical evaluation of the response time of high temperature fiber optic sensors. Sensors and Actuators, A: Physical 2016;243:167-174

[39] Rinaudo P, Torres B, Paya-Zaforteza I, Calderón PA, Sales S. Evaluation of new regenerated fiber Bragg grating high-temperature sensors in an ISO 834 fire test. Fire Safety Journal 2015:71:332-339

[40] CEN (European Committee for Standardization). Eurocode 3: Design of steel structures - Part 1-2: General rules - Structural fire design. Brussels (Belgium), 2005. 
Alos-Moya J., Paya-Zaforteza I., Hospitaler A., Rinaudo P.

Valencia bridge fire tests: Experimental study of a composite bridge under fire (2017) Journal of Constructional Steel Research, 138, pp. 538-554. DOI: 10.1016/j.jcsr.2017.08.008 